\title{
The Determinants of Individual Trade Policy Preferences: International Survey Evidence
}

\author{
Kevin H. O'Rourke \\ (Department of Economics, Trinity College Dublin and CEPR and NBER) \\ and \\ Richard Sinnott \\ (Department of Politics and Institute for the Study of Social Change, \\ University College Dublin)
}

June, 2001

Revised version of a paper presented at the Brookings Trade Policy Forum, May 10-11, 2001, and longer version of a paper to be published in the Brookings Trade Policy Forum proceedings, 2001. The authors thank Elva Hannon for able research assistance. We also thank Ken Benoit, Susan Collins, Kevin Denny, Colm Harmon, Patrick Honohan, Gary King, David Madden, Anthony Murphy, Dani Rodrik, Mike Tomz, Paul Walsh and participants at the Dublin Economics Workshop, ERWIT 2001, the Brookings Trade Policy Forum, and seminars at Queen's University Belfast and Trinity College Dublin for valuable comments, suggestions and econometric advice. 


\section{Introduction}

What determines trade policy? While this may seem to be mainly a question for political scientists, it has become of increasing concern to international trade theorists, faced with the obvious disjunction between the free trade prescriptions of standard trade models, and the protectionist policies pursued by so many governments (Rodrik 1995). The intellectual stakes for economists have increased further with the advent of endogenous growth models, which predict that policies can have important long run growth effects, as opposed to the fairly trivial deadweight losses implied by static constant returns models. Clearly, it is not sufficient to take these policies as exogenous, and examine their implications: to understand growth, the theory seems to be telling us, we need to understand why some countries pursue appropriate policies, and others inappropriate ones.

When faced with such questions, the instinct of economists is to eschew state-centred or cognitive theories, and to reach for the rational choice approach: politicians supply policies; voters and/or interest groups demand them; the institutional environment helps determine the ways in which these demands and supplies interact with each other, and thus the eventual equilibrium. In these models, a key consideration is the determination of individual voter preferences, which in turn depends on the structure of the economy in question. In an environment in which factors are 'stuck' in particular sectors, as in the specific factors model, factors have a direct stake in those particular sectors; thus, management and labor in each sector will agree with each other that their sector deserves protection (if it is an import-competing sector), or that free trade is the best policy (if it is an exporting sector). On the other hand, if factors are mobile between sectors, as in the Heckscher-Ohlin model, then unskilled workers everywhere will have the same interest (since they all earn the same wage), as will skilled workers, and capital, and all other relevant, mobile, factors of production. In this case, 'abundant' factors will favor free trade, and 'scarce' factors will favor protection (Rogowski 1989). Classic economic contributions to the literature, such as Findlay and Wellisz (1982), Mayer (1984), Magee, Brock and Young (1989), and Grossman and Helpman (1994), all assume such a rational choice world, with some adopting a specific factors specification, and others a 
Heckscher-Ohlin one.

On the other hand, there are powerful empirical reasons for believing that interests alone may not provide a complete explanation for the evolution of trade policy: ideas (or ideology) may matter too. Sometimes the ideology is socialist, as in the case of COMECON, while the case of late $19^{\text {th }}$ century Britain arguably provides an example of the power of liberal ideology. ${ }^{1}$ In this paper we take seriously a third possibility: that a preference for economic protectionism among voters is a function of strong feelings of national identity and an associated set of patriotic and nationalist attitudes that include pride in country, sense of national superiority and, at the extreme, antagonistic attitudes towards those who are not part of the nation. Of course, nationalist ideology may have its origins in a conjuncture between identity and group interests, and particularly in a conjuncture between identity and perceptions of inequality (Gellner 1983); the point here, however, is that, whatever their origins, nationalist attitudes are likely to have a certain autonomy and may exercise an independent influence on the way in which individuals react to the opening up of trade and to other globalization issues. ${ }^{2}$

These competing explanations have radically different policy implications. If support for economic protectionism is a function of the material interests of individuals, it can in principle be dealt with by offering side payments that compensate for the losses that result from liberalization. For example, in a specific factors framework workers who have been displaced from declining industries can be given help in relocating to other sectors; ${ }^{3}$ in a Heckscher-Ohlin framework, the problems faced by unskilled workers in rich countries can be reduced by education and training schemes that, in

\footnotetext{
${ }^{1}$ A controversial claim, to be sure: see Irwin (1989) for one view, and Schonhardt-Bailey (1991) for another.

${ }^{2}$ One should be wary of oversimplifying the implications of nationalist ideology for foreign economic policy. Shulman, for example, shows that Quebec, Hindu and Ukrainian nationalists experience both integrationist and protectionist incentives and that policy choices depend on a number of situational factors (Shulman, 2000). One could cite the Republic of Ireland's decision to abandon protectionism in the late 1950s and its subsequent pursuit of European integration as another case in point. However, the main thrust of nationalist ideology, particularly at the mass level, probably remains autarkic; at any event this is the hypothesis tested in the paper.
}

${ }^{3}$ See for example several contributions to Bhagwati (ed., 1982). 
principle, lower unskilled labor supply. If, on the other hand, protectionist policy preferences are rooted in nationalist attitudes, the strategy to alter them will have to be very different, and the strategist may have to be less sanguine about the prospects of success. Of course, the truth may well lie somewhere between these alternatives, with both interests and ideology reinforcing opposition to free trade. In this case it becomes necessary to tease out the relative effects of each, and to identify the conditions under which such effects operate.

In pursuing these questions, this paper starts with rational choice models of policy formation, and asks to what extent does the Heckscher-Ohlin model provide a useful guide to predicting trade policy preferences. This question has often been addressed in the empirical economics literature: typically, authors have used aggregate data to ask whether factor interests or sectoral interests are more important in determining policy preferences. For example, Magee (1978) looked at industry testimony before the US Congress in 1973, and found that labor and capital seemed to have the same interests within each sector, suggesting that a specific factors model is appropriate. More typically, voting behavior has been related to constituency characteristics, either in the context of US Congressional votes on trade-related issues, or in the context of national elections that are assumed to have been fought largely on such issues. ${ }^{4}$

This paper pursues a different strategy. The inquiry is pitched, not at the level of interest groups (where, almost by definition, interests are likely to be determining), or at the level of the electoral constituency (where data on ideological and political variables are likely to be missing), but at the level of individuals or mass public opinion. In so doing, we are following in the footsteps of Balistreri (1997), and Scheve and Slaughter (2001), both of whom use survey data to tackle the question of who is in favor of free trade, and why. As Scheve and Slaughter (citing Rodrik, 1995) point out, individual-level preferences regarding trade must lie at the heart of any rational choice account of policy-formation, but using aggregate data provides only indirect information on agents' preferences, since "policy preferences and institutions together determine policy actions, so the

\footnotetext{
${ }^{4}$ See for example Irwin (1994), or Kaempfer and Marks (1993).
} 
mapping from preferences to actions is not unambiguous" (Scheve and Slaughter 2001, p. 4). ${ }^{5}$

Of course, using survey data has its own limitations. If the Heckscher-Ohlin trade model accurately describes the world, then that has profound (and negative) implications for the impact of North-South trade on Northern wage inequality, and equally profound, but positive, implications for the impact of that same trade on Southern wage inequality. It might well have political implications for the ease with which the transition economies of Eastern Europe can be integrated into the European Union. Finally, it would clearly have intellectual implications for the way in which theorists should specify their models of endogenous tariff formation. Leaving aside measurement problems in attitude research (to which we return below), survey data on their own cannot tell us whether the Heckscher-Ohlin model in fact describes reality; all that they can tell us is that agents' preferences are consistent, or inconsistent, with the predictions of the model. Our claim is that findings of the latter, more cautious, variety are useful, since the determinants of preferences matter in themselves, both intellectually and politically.

The plan of the paper is as follows. Section 2 provides a brief discussion of what theory has to say about the impact of trade on skilled and unskilled wages, since it is this link that leads us to expect a relationship between skill and trade policy preferences. Section 3 introduces the data, including our measures of nationalist attitudes, and discusses the strengths and weaknesses of our evidence relative to the data used by previous authors. Section 4 provides an ordered probit analysis of the determinants of individual trade preferences in 24 countries, including both 'economic' and 'ideological' determinants. Finally, Section 5 concludes by drawing some preliminary inferences and outlining an agenda for future research.

\footnotetext{
${ }^{5}$ Since beginning this project, we have become aware of the simultaneous and independent work being pursued by Anna Maria Mayda and Dani Rodrik (2001), who use the same ISSP survey data as we do, and who reach many of the same conclusions.
} 


\section{Trade and wages: a theoretical digression}

In a simple 2 country, 2 commodity, 2 factor (skilled and unskilled labor) framework the links between trade and wage gaps are clear. Assume that Mexico is abundant in unskilled labor, and that the US is abundant in skilled labor. Let NAFTA reduce the barriers to trade between the two economies: Mexico will export and produce more unskilled-labor intensive products, and the demand for unskilled labor will increase; while it will import more skill-intensive goods, which will lead to a reduced demand for skilled workers, and a fall in the skilled wage. Wage inequality in Mexico will thus fall; unskilled Mexican workers should favor free trade, while skilled workers should oppose it. Of course precisely the opposite will occur in the US: skilled wages will rise and unskilled wages will fall; thus in the US it is the unskilled who should be protectionist, and the skilled who should favor free trade.

There have been several recent trade-theoretic papers exploring the ways in which the links between trade and income distribution become more complicated once we move away from simple $2 \times 2 \times 2$ models. These contributions have been largely motivated by the fact that, while simple Heckscher-Ohlin logic might seem to suggest that globalization should lower skill differentials in the South, in fact differentials have widened in several developing countries (DCs) during the past 20 years. One possibility is that FDI, associated with trade liberalization, might lead to new skillintensive activities being introduced into DCs (Feenstra and Hanson 1996). Under such circumstances, the relative demand for skilled labor could rise in the South. Alternatively, if skilled labor and capital are complementary to some natural resource (e.g. minerals), then liberalization in a resource-rich DC might increase skill premia and inequality overall (Kanbur 1999). Clearly, allowing for more than 2 factors of production, or for links between trade and factor flows, or between trade and technology transfers, leads to theoretical ambiguity regarding the relationship between trade and wages. Nonetheless, it is interesting to ask whether the predictions of simple $2 \times 2$ models help to shed light on policy preferences generated in the admittedly complicated real world.

Even within a simple two-factor framework, however, there is another set of complications 
that have to be faced: not all DCs are homogenous. Instead, they differ greatly in their endowments of capital, labor and skills. Davis (1996) points out that in a 2-factor (capital and labor) world, a country may be globally labor-abundant, but locally capital-abundant, in the sense that it is capital-abundant relative to other countries in the same "production cone"; for such a country, liberalization lowers wages. By implication, a middle-income country such as Mexico might be skill-abundant relative to countries like China and India; they might therefore protect their unskilled-labor-abundant sectors; and they might thus see skill premia rising on liberalization (Slaughter 2000; Wood 1997). There is in fact evidence that unskilled-labor intensive sectors received the most protection in countries such as Mexico and Morocco prior to liberalization (Currie and Harrison 1997; Hanson and Harrison 1999).

The argument may have some relevance for this study. With the exception of the Philippines, our data set does not include any third world countries (see below); rather, it contains data for rich countries, and for the transition economies of Eastern Europe. We will be interested to see whether there are different determinants of trade policy preferences in the latter group of economies than in the former; but the Davis article reminds us that while these countries may be poor relative to the West, they are rich, and skill-abundant, relative to most of the rest of the world. In that sense, our sample is a truncated one, and the results need to be interpreted in that light.

In particular, Heckscher-Ohlin theory predicts that the highly-skilled will favor free trade in the most skill-abundant countries (such as the USA): in these countries, a regression explaining protectionist attitudes should find a negative coefficient on skills. Whether the coefficient on skills in the least skill-abundant country in our sample should be positive or negative depends entirely on where that country fits in terms of the world-wide hierarchy of skill-abundance; the sign of the coefficient is thus a priori unclear. In order to test Heckscher-Ohlin theory, therefore, we will pursue two strategies. First, we will estimate models (for the entire sample of countries) of the form:

$$
\text { PROTECT }_{\mathrm{ij}}=\alpha_{\mathrm{i}}+\beta_{1} \text { SKILL }_{\mathrm{j}}+\beta_{2} \text { SKILL }_{\mathrm{j}}^{*} \operatorname{GDPCAP}_{\mathrm{i}}+\beta_{3} \mathrm{X}_{\mathrm{ij}}+\varepsilon_{\mathrm{ij}}
$$


where PROTECT $\mathrm{Pij}_{\mathrm{ij}}$ is the extent to which individual $\mathrm{j}$ in country $\mathrm{i}$ is protectionist; $\mathrm{SKILL}_{\mathrm{j}}$ is a measure of the individual's skill; GDPCAP ${ }_{\mathrm{i}}$ is the GDP per capita of country $\mathrm{i}$; and $\mathrm{X}_{\mathrm{ij}}$ is a vector of control variables. ${ }^{6}$ In this set-up, the test of whether Heckscher-Ohlin theory holds is the sign of the interaction term, $\beta_{2}$, which should be negative, since in richer countries high-skilled workers should be more in favor of free trade (i.e. less protectionist). ${ }^{7}$

Second, we run country-specific regressions of the form

$$
\text { PROTECT }_{\mathrm{j}}=\alpha+\beta_{1} \mathrm{SKILL}_{\mathrm{j}}+\beta_{2} \mathrm{X}_{\mathrm{j}}+\varepsilon_{\mathrm{j}}
$$

and compare the $\beta_{1}$ coefficients across countries. Again, the test of Heckscher-Ohlin theory is whether these coefficients are systematically lower (i.e. more negative) in richer, more skill-abundant countries.

\section{The data}

What do we need to accomplish our objectives? We need a data set that provides information on individuals' trade preferences, socio-economic position, socio-demographic characteristics and political attitudes. Since the Heckscher-Ohlin model predicts that skill levels will have different implications for trade policy preferences in different countries, the data should be cross-national in scope.

What we have are data provided by the 1995 International Social Survey Programme (ISSP) module on national identity. The ISSP is an international consortium of survey research agencies that

\footnotetext{
${ }^{6}$ Equations (1) and (2) are used for expositional purposes; however, because of the nature of the data, we actually estimate non-linear ordered probit models, as explained below. As shown the specification incorporates country dummies, but we also experiment by running regressions without these country fixed effects.

${ }^{7}$ We used country GDP per capita rather than educational attainment variables for reasons given in Section 4; this amounts to assuming that GDP per capita is highly correlated with country endowments of human capital.
} 
conducts comparative public opinion research on economic, social and political issues across a wide range of countries on a regular basis. The sample in each country is a national representative random sample of the adult population designed to achieve a norm of 1,400 cases and, in any event, not less than 1,000 cases. Questionnaires are designed to be completed in 15 minutes (not including a standard set of socio-demographic questions); questionnaires are also designed to be suitable for selfadministration. ${ }^{8}$ The ISSP national identity survey was conducted in twenty-four countries in 1995 96. The countries concerned were: Australia, West Germany, East Germany, Great Britain, the USA, Austria, Hungary, Italy, Ireland, the Netherlands, Norway, Sweden, the Czech Republic, Slovenia, Poland, Bulgaria, Russia, New Zealand, Canada, the Phillippines, Japan, Estonia, Latvia and Slovakia. The questionnaire (as implemented in the Republic of Ireland) is available on request. Our dependent variable is the scaled response to a question that asked respondents how much they agreed or disagreed with the statement that their country 'should limit the import of foreign products in order to protect its national economy' (question 6 in the survey). While in an ideal world one would like to have a battery of questions on trade policy preferences, we take this to be a reasonable operationalization of protectionist sentiment. ${ }^{9}$ The data set also provides individual-level measures of a range of demographic, socio-economic and political variables. Among the socioeconomic variables, the most valuable from the point of view of testing the implications of trade theory is the respondent's skill level. This is arrived at by coding the answers to questions on respondents' occupation using the International Labour Organisation's ISCO88 (International Standard Classification of Occupations) coding scheme. ISCO88 is a radical revision of the ILO's previous occupational coding scheme (ISCO68). The main thrust of the revision makes ISCO88

\footnotetext{
${ }^{8}$ Full details on the ISSP consortium, including details on membership, rules and procedures and availability of datasets and technical reports can be obtained at http://www.issp.org/info.htm

${ }^{9}$ One might argue that the inclusion of the phrase 'in order to protect its national economy' is unfortunate in that it could bias responses in a protectionist direction by assuming that limiting imports is in some sense good for the economy. On the other hand, this is the way protectionist measures are defended in political discourse. Furthermore, we are interested in the relationships between this variable and our independent variables, not in estimating the absolute levels of support for protectionism. This objective is much less vulnerable to any response bias that may exist.
} 
particularly relevant for our purposes. As Ganzeboom and Treiman put it, ' $\ldots$ the logic of the classification is mostly derived from skill requirements at the expense of industry distinctions' and the overall effort may 'be seen as an attempt to introduce more clear-cut skill distinctions into ISCO88' (Ganzeboom and Treiman 1996, p. 206). They go on to illustrate this point by noting that 'whereas in ISCO68 all 'Textile Workers' were organized in a single minor group, irrespective of their skill level (thereby precluding distinctions based on skill), textile workers are now spread out over three different minor groups, depending on whether they do elementary labor, operate machines, or perform craft work' (ibid.). Similar changes were implemented for other manual occupations and, analogously, for non-manual occupations. While a complex coding scheme of this sort allows for very fine distinctions between different occupations, we are interested in the four main skill categories provided by ISCO88. In brief, these are: (1) 'elementary occupations' (i..e. 'manual labor and simple and routine tasks, involving... with few exceptions, only limited personal initiative' (ILO 1990, p.7)); (2) 'plant and machine operators and assemblers; craft and related trades workers; skilled agricultural and fishery workers; service workers and shop and market sales workers; clerks;' (3) 'technicians and associate professionals;' and (4) 'professionals.' A fifth group, 'legislators, senior officials and managers,' do not have a skill coding under this four-step skill classification and were included as a separate, fifth, skill category. Finally, we excluded members of the armed forces, since it was unclear what their skill levels were.

Unfortunately, our use of the occupational coding in the 1995 ISSP survey created a complication which had to be faced: the survey which we are using coded occupation in three different ways, depending on the country in question. The ISCO88 coding scheme was used in 12 cases: Australia, Hungary, Ireland, East and West Germany, Czech Republic, Poland, Slovenia, Canada, Russia, Slovakia, and Latvia. The earlier ISCO68 scheme was used in 5 countries: Norway, New Zealand, Bulgaria, Austria, and USA. Finally, a further 6 countries (Britain, Italy, Netherlands, Sweden, Japan and the Philippines) used a variety of national coding schemes. Estonia provided no occupational coding. It was, however, possible to reclassify the ISCO68 countries' occupation codes 
according to the ISCO88 classification. We were also able to derive an approximation to the ISCO skill classification from the country-specific occupational codes used in Britain, the Netherlands, and the Philippines. This left us with skill data for 20 of our 24 countries; we have had to omit the other four (Estonia, Italy, Sweden and Japan) when estimating models involving skill. ${ }^{10}$

In addition to the foregoing reasonably objective economic variables, we will make use of a subjective economic variable, namely the stated willingness of people to move from one location to another in order to improve their standard of living or their work environment. Respondents were asked: "If you could improve your work or living conditions, how willing or unwilling would you be to move to another neighbourhood or village; another town or city within this county or region; another county or region; outside [named country]; outside [named continent]?” Based on the responses to these questions, we derived two binary variables, indicating whether or not individuals were nationally mobile, and internationally mobile. ${ }^{11}$ Arguably, those willing to relocate within the country should be more sanguine about the dislocation implied by free trade than those who are immobile. The rationale behind including the international mobility variable is to test Rodrik's (1997) argument that globalization is currently favoring internationally mobile factors of production (i.e. physical and human capital) over immobile factors such as unskilled labor. ${ }^{12}$ By the same token, we also make use of a question which asks whether the respondent had ever lived abroad, on the basis that previous experience of living abroad may provide a signal regarding willingness to move again.

The ISSP national identity data set includes a wide range of indicators of nationalist attitudes. Rather than focusing on just one or two of these as indicators of what is, after all, a complex phenomenon, the approach taken here is to seek to identify an underlying dimension (or dimensions)

\footnotetext{
${ }^{10} \mathrm{We}$ checked whether our results are dependent on our recoding schemes, by running separate regressions for our 12 ISCO88 countries, and the other 8 countries for which we were able to obtain skill data. The results (available on request) were reassuringly similar.

${ }^{11}$ Details available on request.

${ }^{12}$ Although immigration to the US, for example, has become increasingly unskilled in recent decades (Borjas 1999).
} 
of nationalism that would be measured by a subset (or subsets) of the items. An added advantage of this approach is that using multiple items to measure the same basic concept should improve the reliability of measurement. Factor analysis provides a statistical means of identifying the hypothesized dimension or dimensions. ${ }^{13}$ A combination of a priori assessment of the individual items and exploratory factor analysis suggested a strategy of focusing on the following seven items (versions implemented in Ireland, other country/nationality labels substituted as appropriate):

- "Generally speaking, Ireland is a better country than most other countries"

- "The world would be a better place if people from other countries were more like the Irish"

- "I would rather be a citizen of Ireland than of any other country in the world"

- $\quad$ "It is impossible for people who do not share Irish customs and traditions to become fully Irish"

- "People should support their country even if the country is in the wrong"

- "Ireland should follow its own interests, even if this leads to conflicts with other nations"

- "How important do you think each of the following is for being truly Irish?"... ......."to have been born in Ireland"

In each case, respondents were asked to rank their responses along a scale, in the case of the first six items, from 1 (strongly disagree) to 5 (strongly agree) and, in the case of the seventh item, from 1 (very important) to 4 (not at all important). The seventh item was reordered to make it consistent with the other six. Principal components analysis of these responses yielded two factors or underlying dimensions of nationalist attitudes. As can be seen from the rotated factor loadings in

\footnotetext{
${ }^{13}$ Factor analysis is a generic term often used to cover both principal components analysis and factor analysis strictly speaking. Both are techniques that can be applied to a set of variables '... when the researcher is interested in discovering which variables in the set form coherent subsets that are relatively independent of one another. Variables that are correlated with one another but largely independent of other subsets of variables are combined into factors. Factors are thought to reflect underlying processes that have created the correlations among variables' (Tabachnick and Fidell 2001, p. 582).
} 
Table 1, the first factor is a straightforward preference for and sense of the superiority of one's own country (here labeled patriotism). The second factor identifies a narrow or exclusive sense of nationality combined with a degree of chauvinism of the "my country right or wrong" variety (here labeled chauvinism). On the basis of this analysis, patriotism and chauvinism scores have been calculated by averaging responses across the relevant subsets of items identified in the factor

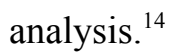

Table 2 provides summary statistics for our key variables. As mentioned, 'Protect' ranges from 1 to 5, as do 'patriotism' and 'chauvinism'. 'Skill' also ranges from one to five, reflecting the fivefold classification above; note, however, that we do not include such a variable in our regression analyses, since there is no reason to believe that the gap between the first and second skill levels, say, is equivalent in its effects to the gap between the second and third levels. For this reason, we incorporate skill into the analysis by introducing a variety of dummy variables. The mobility variables are both categorical; 0 denotes immobility, and 1 mobility. As the table makes clear, there is a lot of variation both between and within countries, which Section 4 will exploit.

This brings us to the advantages and disadvantages of our data set compared to the data used by other authors, and in particular those used by Scheve and Slaughter (2001). The big disadvantage is that we do not have data on the sector in which respondents are employed; thus, we cannot directly confront the Heckscher-Ohlin and specific factors world views, as other authors have done. ${ }^{15}$ The big advantage is that we have data for not just one country, but 20. Scheve and Slaughter find that lowskill workers in the USA favor protection, which is useful evidence consistent with the HeckscherOhlin model; but such a finding on its own does not preclude the possibility that low-skill workers everywhere have the same attitudes (which would be completely at variance with the predictions of

\footnotetext{
${ }^{14}$ The Cronbach's alpha reliability coefficient for the three-item patriotism scale is 0.68 and the item-total correlations vary from 0.41 to 0.57 . The four-item ethnic chauvinism scale is somewhat less satisfactory in this regard: an alpha of 0.53 and inter-item correlations ranging from 0.31 to 0.36 .

${ }^{15}$ Nor do we have data on home ownership, another variable which Scheve and Slaughter (2001) found to be important.
} 
such a model). ${ }^{16}$ Our data set allows us to explore whether skill has a differential impact on attitudes across countries, and thus allows for a cleaner test of the Heckscher-Ohlin predictions. Finally, our data allow us to test these 'economic' relationships while controlling for the effect of variations along two dimensions of nationalist ideology.

\section{The determinants of attitudes towards protection}

We begin by looking at some crude country-level correlations. Table 3 takes the country means of seven variables (given in Table 2), and calculates the cross-country correlations between these variables. While this ignores the vast range of variation in attitudes within countries, the data are nonetheless instructive. Richer countries have higher skill levels, and higher rates of internal mobility, than poorer countries; they also show more patriotism, and less chauvinism. There is a strong positive correlation $(+0.691)$ between protectionism and chauvinism, but only a weak correlation between protectionism and patriotism. Skill, mobility and income per capita are all associated across countries with pro-free-trade sentiments, rather than with protectionism.

However, our interest is in the determinants of protectionism at the individual level and Table 4 provides some exploratory analysis. In all cases, the dependent variable is 'protect', which as already mentioned is an ordered variable running from 1 to 5 . We therefore used ordered probit methods in estimating our relationships.$^{17}$ In each case, there is assumed to be a latent variable, PROTECT ${ }^{*}$, related to the independent variables as in equation (1):

$$
\text { PROTECT }_{i j}^{*}=\alpha_{i}+\beta_{1} \text { SKILL }_{j}+\beta_{2} \text { SKILL }_{j}^{*} \text { GDPCAP }_{i}+\beta_{3} X_{i j}+\varepsilon_{i j}
$$

There are also 4 cutoff points, $\mu_{1}-\mu_{4}$, such that protect takes the value 1 if PROTECT ${ }^{*}$ lies below $\mu_{1}, 2$

\footnotetext{
${ }^{16}$ For example, it might be the case that better-educated people everywhere are more flexible and able to cope with the rigors of the market; or even that they are more likely to understand the intellectual case for free trade.

${ }^{17}$ For an introduction, see Greene (2000), Chapter 19.
} 
if PROTECT ${ }^{*}$ lies between $\mu_{1}$ and $\mu_{2}, 3$ if PROTECT ${ }^{*}$ lies between $\mu_{2}$ and $\mu_{3}, 4$ if PROTECT ${ }^{*}$ lies between $\mu_{3}$ and $\mu_{4}$, and 5 if PROTECT ${ }^{*}$ lies above $\mu_{4}$. The disturbance term is assumed to be normally distributed.

In this model, the probability that protect will take on the value 1 , say, is the probability that

$$
\text { PROTECT }^{*}=\beta^{\prime} Y+\varepsilon \quad<\mu_{1}
$$

(where $\mathrm{Y}$ is the vector of all independent variables), which is equivalent to the probability that

$$
\varepsilon<\mu_{1}-\beta^{\prime} Y
$$

or

$$
\varphi\left(\mu_{1}-\beta^{\prime} Y\right)
$$

where $\varphi$ is the standard normal distribution. The probabilities that protect will take on any of the other possible values are similarly constructed: they depend on the respondent's characteristics, $Y$; the vector of estimated coefficients, $\beta$; the cutoff points, which are parameters to be estimated alongside $\beta$; and the standard normal distribution.

It follows that the marginal effect of changing an independent variable on the probability of a given outcome depends not only on $\beta$, but on the standard normal density function evaluated using a particular choice of $Y$. A significant positive coefficient implies that changing the relevant independent variable increases the probability that protect takes on the value 5, and reduces the probability that protect takes on the value 1 . The marginal effect of changing such a variable on the probability that protect takes on the values $2-4$ is, however, a priori unclear. Initially, we will simply estimate ordered probit models, and will loosely speak of variables being either positively or negatively related to protectionism; marginal effects will be estimated later.

In nearly all cases, we include a full set of country dummy variables, to take account of country-level effects operating on all individuals within a country (coefficients not reported). Each column in Table 4 indicates whether these dummies have been included or not. For all other variables 
the table reports the coefficient, with the t-statistic in parentheses below.

Equation 1 provides a preliminary examination of the impact of skill. Skill345 is a binary variable which takes the value 1 if the respondent's skill level is either 3, 4 or 5, and zero if his or her skill level is 1 or $2 .{ }^{18}$ In what follows, we will loosely speak of the variable as indicating whether a respondent is high-skilled or not. The equation relates protectionism not only to this variable, but to Skill345 interacted with the country's GDP per capita (measured in thousands of US dollars). ${ }^{19}$ The results indicate that the high-skilled are more predisposed towards free trade than the low-skilled, and the interaction term suggests that this effect is greater in rich countries than in poor countries, just as Heckscher-Ohlin theory predicts. Equations 2 through 9 indicate that the latter finding is quite robust to the inclusion of other variables (although the former is not): since it is the interaction term which is crucial in testing Heckscher-Ohlin theory, it seems that, so far, preferences are entirely consistent with that theory.

Equation 2 in Table 4 establishes that patriotism and chauvinism are both positively related to protectionism, as expected, with chauvinism having a larger impact. A glance across the table confirms that these findings are also extremely robust to the choice of specification: the hypothesis that nationalism is an important determinant of attitudes towards trade policy is, on the basis of these results, confirmed. However, nationalist attitudes are not all-important: taking them into account still leaves scope for skill differentials to have an effect in ways that, as noted above, are consistent with economic theory.

National mobility has no consistent effect on attitudes, which is perhaps a surprise, but those who consider themselves to be internationally mobile, as well as those who have lived abroad in the past, are more positively disposed towards trade, supporting Rodrik’s (1997) arguments. Older people tend to be more protectionist, as are rural dwellers, women, Roman Catholics, and those in marital

\footnotetext{
${ }^{18}$ We will explore other skill-related specifications later.

${ }^{19}$ These are the World Bank's data for 1995 PPP-adjusted GDP per capita, in 1995 international dollars.
} 
relationships (although the latter finding is not robust across specifications). There is a statistically weak but positive link between trade union membership and public sector employment and protectionism, while the self-employed are more likely to be free traders, as are those who can be identified as right wing on the basis of the political party they support. ${ }^{20}$ The last three variables measure familiarity with, and attitudes towards, relevant regional associations (e.g. the European Union in Ireland's case). There was a negative but statistically insignificant relationship between familiarity with the association and protectionism; but those who felt that their country did not benefit from the association, as well as those who felt that their country should be protecting its independence, were more likely to be protectionist. ${ }^{21}$

Finally, we experimented with our specification by including country GDP per capita, with and without country dummies. ${ }^{22}$ With country dummies omitted, richer countries tend to be associated with a higher preference for free trade, but this relationship goes away (and indeed the sign of the coefficient is reversed) when country dummies are introduced. More importantly for our purposes, the sign of the interaction term between high skills and GDP per capita remains negative and significant in both these specifications. Another noteworthy feature of these regressions is that when country dummies are excluded, the coefficient on Roman Catholicism become much larger and more statistically significant, suggesting that variation in religious beliefs might be explaining crosscountry differences in protectionist attitudes, as well as within-country differences. Roman Catholic social teaching has traditionally been more skeptical of the market than some brands of Protestantism, so these correlations make intuitive sense; on the other hand, Catholicism could be proxying across our set of countries for the Mediterranean region, which might have more protectionist attitudes for reasons unrelated to religion.

\footnotetext{
${ }^{20}$ Data on these variables are not available for all countries.

${ }^{21}$ Again, these regional integration questions were only asked in a subset of our countries.

${ }^{22}$ An additional country dummy is of course dropped in the specification involving both country dummies and GDP per capita.
} 
Tables 5 and 6 explore the links between skill levels and preferences in greater detail. ${ }^{23}$ The first regression in Table 5 uses five dummy variables reflecting the five skill categories, rather than the single high-skill variable used in Table 4, and as before introduces them into the regression both on their own, and interacted with GDP per capita. Using this finer grid does reveal several relationships consistent with Heckscher-Ohlin theory. Most importantly, the coefficient on Skill1 is negative, suggesting that the lowest skilled are in favor of free trade; but the interaction term is positive, suggesting that the association between being low skilled and having protectionist preferences rises with incomes. The coefficients imply that in countries with per capita incomes below $\$ 11942$ in 1995 (roughly \$1000 more than incomes in Slovenia), belonging to the lowest skill category is associated with a preference for free trade, but that in countries with incomes higher than that amount those in the lowest category are more likely to be protectionist. We take this to be strong evidence in favor of the Heckscher-Ohlin hypothesis. A similar sign pattern emerges for Skill2, although the coefficient on Skill2 itself (as opposed to its interaction term) is statistically insignificant. For Skill3 and Skill4 (but not Skill5), the sign of the interaction term becomes negative, again consistent with the theory, although the coefficients are statistically insignificant.

The second regression drops the interaction terms, but allows the coefficient on the high-skill variable to vary, depending on whether the economy is western, a transition economy, or the Phillippines. In the West, high skills are strongly associated with a preference for free trade. They are also strongly associated with such a preference in the transition economies, although the coefficient is only about half the size as in the West. Finally, the relationship in the Phillippines is insignificant. Again, this is suggestive evidence in favor of the Heckscher-Ohlin world view.

Table 6 pursues the same issue in a different way, again using the single 'high-skill' dummy variable. It runs identical regressions (data permitting) for each country individually. While interesting patterns emerge for several of the other variables, our focus here is on the skill variable. Figure 1 plots the 'high-skill' coefficient, for each country, against that country's GDP per capita. A

\footnotetext{
${ }^{23}$ Country dummies were included for all regressions in Table 5, and Tables 7 through 9.
} 
clear negative association appears between the two variables (the correlation coefficient is -0.634 ): that is, the richer the country, the more negative (less positive) is the association between high skills and protectionist attitudes. To the left of the picture, there is a cluster of poorer countries for which the coefficient on high skills is either close to zero or positive, while to the right of the picture are the rich countries in which high skills are clearly associated with a preference for free trade, rather than protection..$^{24}$

Again, we take Figure 1 to be strong evidence in favor of the Heckscher-Ohlin perspective. Of course, it might be objected that high skills are only associated with protectionism in 3 countries, and that the t-statistics fall below conventional levels in all three cases (see Table 6); but we think that there is a convincing counter-argument (already suggested in Section 2), which, however, we are unable to provide evidence for given our current dataset. Our sample of countries, while 20 times bigger than the samples used in previous studies, only contains 20 countries. There are many, poorer countries in which the high-skilled might be even more protectionist than in Bulgaria and Slovakia: one could imagine the negatively sloped relationship in Figure 1 extending further to the left, with the countries of the world as a whole more evenly divided between those where skills are associated with protectionism, and those where skills are associated with liberal attitudes towards trade. Of course, this is pure speculation on our part: nonetheless, the results we are able to obtain from these data seem entirely consistent with the insights of Eli Heckscher and Bertil Ohlin.

The evidence in Figure 2, which plots the same coefficients against the average years of schooling in each country, ${ }^{25}$ is less compelling. The correlation is much weaker $(-0.0993)$, and this is disturbing, since theory says that attitudes should be related to factor endowments, rather than income per capita. (The rationale for using income per capita is thus that it is correlated with the skill level of

\footnotetext{
${ }^{24} \mathrm{We}$ also ran a regression over the entire sample which included country dummies, the high-skill variable, and the high-skill variable interacted with country dummies (one country was of course omitted). The interaction terms were jointly highly statistically significant (and several individual interaction terms were also statistically significant), indicating that the skill coefficients are indeed significantly different across countries.

${ }^{25}$ Taken from Barro and Lee (2000).
} 
the population.) As can be seen from the figure, however, the Barro-Lee figures for schooling in several transition countries are very high: for example, average schooling is higher in Slovakia, Bulgaria, Latvia and Poland than in the Netherlands, Ireland, and Austria. We doubt whether these figures provide a genuine reflection of the economically relevant human capital endowments of these economies, and thus doubt the usefulness of Figure 2 as a test of Heckscher-Ohlin theory.

Leaving aside the testing of trade theory for a moment, what other insights can be gleaned from Table 6? Patriotism and chauvinism are significantly related to protectionist attitudes in virtually all countries, with the size of the coefficients being fairly consistent throughout. Clearly, our findings regarding nationalism and trade policy preferences reflect a quite general phenomenon (at least in this sample of countries), rather than depending on strong correlations in a few countries. There are several exceptions to the general rule that the old are more protectionist: they are significantly more likely to favor free trade in East Germany, Poland and Estonia, all former Communist countries; and coefficients are statistically insignificant in several countries. The finding that women tend to be more protectionist than men is, however, a fairly general one.

Table 7 investigates the data further, by estimating models separately for various sub-samples of the data. The first four columns take a further look at cross-country variations in the data by splitting the sample into its western and former Communist components. ${ }^{26}$ The high-skill coefficient in column 2 is positive (and statistically significant at the $10 \%$ level) in the east, and the interaction term between skills and GDP is negative and significant, consistent with both Heckscher-Ohlin theory and Figure 1. The results in column 2 suggest that in countries with per capita incomes below $\$ 4215$ (slightly lower than the Russian income) high-skilled workers are more likely to be protectionist, whereas they are more likely to support free trade in countries with higher incomes. The interaction term is insignificant within the west, which is again consistent with Figure 1: there may be too little variation in the western data to pick up any relationship here.

The impact of gender appears to be much stronger in the west, although it is still strong in the

\footnotetext{
${ }^{26}$ The Phillippines is not included in either sample.
} 
east (consistent with Blanchflower (2001), who finds that women are less satisfied with democracy); but age appears only to affect attitudes in the east. Unemployment is weakly associated with protectionist attitudes in the west, but not at all in the east: attitudes towards being unemployed may be quite different in a society undergoing rapid structural change than in a typical western economy. Interestingly, the impact of being rural appears to be almost identical in east and west: this is at odds with the intuition that western farmers should be more protectionist, since they are less competitive and more dependent on protection than their eastern counterparts. Of course agriculture is not the only rural industry, but it is the main one; the data are consistent with other rural characteristics of a sociological or even cultural nature driving these correlations.

We estimated the model for men and women separately; the results are given in columns 5 and 6. The most notable difference to our mind is that while age appears to matter for men, it does not matter for women. We were also interested in whether the gender effect was due to the fact that women are less likely to be in the labor force than men. We therefore estimated the model separately for those in the labor force and those outside it; the results (given in Table 8) suggest that the gender effect is not due to lower female labor force participation, since the gender effect is actually stronger for those in the labor force than for those outside it. ${ }^{27}$

The last two columns in Table 7 address the issue of whether those reporting themselves to be immobile (within the country) are less influenced by their skill type than those who are mobile; the reason for the question is that, arguably, the immobile should care more about their sector of employment (assuming that regions are largely dominated by particular industries). The hypothesis is rejected in that the interaction between skills and GDP per capita (the test of Heckscher-Ohlin theory) is even stronger for the immobile than for the mobile. (We also experimented by including interaction terms between skill and mobility in various models: but these interaction terms are always

\footnotetext{
${ }^{27}$ Moreover, the gender effect remains unchanged when a labor force dummy variable is included in the model, estimated over the full sample (results available on request). We counted those in full-time and part-time work, as well as the unemployed, as being in the labor force. We could also have included those working less than 15 hours a week, and relatives assisting, but there were too few respondents in these categories (less than 500 across all countries) for this to be worthwhile.
} 
insignificant.)

Finally, Table 9 explores the effect of age on protectionist attitudes in greater detail.

Consistent with our expectations, age squared has a negative coefficient, suggesting that the marginal effect of age declines as respondents get older. Age remains insignificant in the west, but important in the east: could it be that the overall correlation between age and attitudes is simply being driven by the length of time over which east-bloc respondents were exposed to Communist ideology? Two pieces of evidence suggest not. First, columns 4-6 in Table 9 introduce an interaction term between skill and age. In the west, the term is negative (and significant at the $12.5 \%$ level), suggesting that the high-skilled become more pro-free trade the older they get. If respondents' human capital increases with age, as the labor economics literature suggests, then this is precisely what one would expect. On the other hand, in the east the high-skilled become more protectionist the older they get; which is consistent with the skills acquired under Communism being largely irrelevant to a modern economy, and to these individuals' position in society being threatened by liberalization. ${ }^{28}$ The second piece of evidence suggesting that age is influencing attitudes through economic channels is given in Table 8: it shows that the impact of age on protectionist attitudes is much larger for those in the labor force than for those not in it.

So much for statistical significance: what about the quantitative impact of these variables on attitudes towards protection? In order to answer this question, we began by estimating the model in column 4 of Table 4, and then set all right hand side variables equal to their median values. Having done that, we calculated the impact of changing each individual independent variable on the probabilities that 'protect' would take on each of the values 1 to 5 . For binary variables, we considered the impact of changing the variable from zero to one; for other variables we explored more complicated changes, as discussed below.

Our point estimates of the coefficients and cutoff points, together with the assumption that

\footnotetext{
${ }^{28}$ Indeed, labor economists have found that the 'returns to experience obtained under communism fell during the transition" (Svejnar 1999, p. 2839).
} 
other variables are set equal to their median values, produce a point estimate of the impact of changing a given independent variable on the dependent variable. On the other hand, our coefficients are estimated with uncertainty. We therefore estimated our impact effects with $95 \%$ confidence intervals, to reflect the fact that different samples would have produced different coefficient estimates. ${ }^{29}$ The results are given in Table 10.

The first panel simply presents the simulated probabilities that an observation will take on any of the five values of the dependent variable, protect. As can be seen, there is nearly a $20 \%$ probability that protect takes on the value 3 , a $38 \%$ probability that it takes on the value 4 , and a $31 \%$ probability that it takes on the value 5 . The panels immediately below indicate the impact of changing our nationalism variables on all five probabilities; in the following discussion we focus on the probability that protect takes on the value five. Increasing patriotism from its $40^{\text {th }}$ to its $60^{\text {th }}$ percentile increases the probability that protect take on the value 5 by 2 percentage points, with a $95 \%$ confidence interval of 1.79 to 2.28 percentage points. Changing chauvinism from its $40^{\text {th }}$ to $60^{\text {th }}$ percentile increases the probability that protect takes on its highest value by 5.8 percentage points. If these two variables are changed from their $20^{\text {th }}$ to their $80^{\text {th }}$ percentiles, the impact on protect is enormous: the probability of the most protectionist response occurring increases by 10.1 percentage points in the case of patriotism, an increase of $32 \%$ over the benchmark simulated probability. In the case of chauvinism, the impact is to increase the probability that protect equals five by 19.8 percentage points, an increase of $64 \%$ (with a $95 \%$ confidence interval of 18.4 to 21.2 percentage points). These are huge effects by any standards.

No other variable has an impact as big as chauvinism, although some come close. The interaction term between high-skill and GDP per capita in the equation indicates that the effect of being high-skilled on protectionist attitudes depends on how rich the country is. The next three panels therefore indicate the impact of being high-skilled in economies with GDPs per capita of $\$ 5000$,

\footnotetext{
${ }^{29}$ All results were produced using Clarify, as described in Tomz, Wittenberg and King (1999) and King, Tomz and Wittenberg (2000).
} 
$\$ 15000$ and $\$ 25000$ respectively. As the regression results (and Heckscher-Ohlin logic) suggest, the impact on protectionism is much greater in the richer countries. Thus, the probability that protect is 5 declines by only 2.3 percentage points in the poorest country, but by 5.5 percentage points in the middle-income country, and by 8.4 percentage points in the rich country (a fall of 27\%). Clearly, skill has a large effect on preferences in rich countries.

The only other variable to matter to this extent was gender: being a woman increases the probability of the most protectionist response by 7.4 percentage points, or $24 \%$. This is clearly a large effect. Being internationally mobile reduces the probability that protect takes on the value five by 4 percentage points, while never having lived abroad increases that probability by almost the same amount (3.6 percentage points). The other variables do not have a particularly large effect on attitudes.

We then generated the simulated probabilities implied by the model given in column 5 of Table 4. This allowed us to explore the impact of further variables, not available for all countries, on preferences. The simulated probability that protect would take on the value 5 was equal to nearly $26 \%$; being a rural dweller increases this probability by 4.4 percentage points, but being unemployed only increases it (surprisingly, it might be argued) by 2.1 percentage points. Belonging to a trade union has almost no impact on attitudes, which again seems surprising; but being self-employed reduces the probability of an extreme protectionist response by some 2.6 percentage points.

\section{What have we learned?}

There are a number of key results from this study.

First, protectionist attitudes are strongly related to both patriotism and chauvinism; this is a quite general result across countries, and the effect is quantitatively as well as statistically significant. To that extent, it would appear that trade policy preferences are heavily influenced by non-economic, in this case cultural or ideological, factors. Nationalism is, of course, a complex phenomenon with many roots, including, as noted above, adverse economic experiences and conditions. A totally 
economic-determinist or reductionist explanation of nationalism is, however, implausible. It seems safe, therefore, to conclude that nationalist attitudes exercise some autonomous influence and are a significant factor in the genesis of protectionist policy preferences.

The second result is that, even when cultural or ideological factors are taken into account, skill matters for policy preferences, and the effect that skill has on those preferences varies across countries in ways which are consistent with Heckscher-Ohlin theory. Roughly speaking, in countries with per capita incomes below $\$ 12000$ the lowest skilled tend to be more in favor of free trade, while they tend to be more protectionist in countries above that income threshold. Belonging to one of the higher skill categories only shifts attitudes in a slightly more liberal direction in poor countries; the effect is a large one in rich countries. Finally, there seems to be a strong negative relationship between the impact of skills on protectionist attitudes, on the one hand, and income per capita on the other. That is, high skills are generally associated with a preference for free trade, and this effect is stronger in richer countries than in poorer countries. Indeed, in some of the poorest countries in our truncated sample, high skills are, albeit weakly, associated with a preference for protection.

Third, we have found evidence of a pronounced gender gap regarding trade policy preferences, which is quantitatively important and apparently consistent across countries. We have no explanation for this phenomenon, though we note that it is consistent with findings regarding the persistence of gender differences in support for European integration even after controlling for the effects of a wide range of other variables (Wessels, 1995, 111-114). ${ }^{30}$

In terms of the economic debates surrounding the determinants of protectionist attitudes, we have, as stated, found evidence broadly consistent with the Heckscher-Ohlin viewpoint. What we have not been able to do, given the data we are currently working with, is to compare the impact of skills on protectionist attitudes with the impact of the sector of employment. Nor have we been able to follow Scheve and Slaughter in exploring the impact of home ownership. We will shortly have

\footnotetext{
${ }^{30}$ Similarly, Carol Graham and Stefano Pettinato find that Latin American men are more likely to have pro-market attitudes (Graham and Pettinato 2001), and to agree with the proposition that trade is 'very important' to their country's prosperity (Graham and Pettinato forthcoming).
} 
access to a dataset from the Republic of Ireland that includes both these variables, and we intend to pursue these questions via this avenue; unfortunately, that analysis, like that of Scheve and Slaughter, will lack a cross-country comparative dimension. However, it is our intention in the future to organize the collection of relevant data across a broad range of countries that will allow us to address all these issues on an appropriate comparative scale. 


\section{References}

E.J. Balistreri (1997), "The performance of the Heckscher-Ohlin-Vanek model in predicting endogenous policy forces at the individual level," Canadian Journal of Economics 30, pp. 1-17.

D. Blanchflower (2001), "Unemployment, well-being and wage curves in Eastern and Central Europe," mimeo, Dartmouth College (January).

R.J. Barro and J.-W. Lee (2000), "International data on educational attainment: updates and implications," Harvard Center for International Development Working Paper No. 42. (Cambridge MA: April). Data available at http://www.cid.harvard.edu/ciddata/ciddata.html

J. Bhagwati (1982 ed.), Import Competition and Response (Chicago: The University of Chicago Press).

G. Borjas (1999), Heaven's Door: Immigration Policy and the American Economy (Princeton, N.J.: Princeton University Press).

J. Currie and A.E. Harrison (1997), "Trade reform and labor market adjustment in Morocco," Journal of Labor Economics 15, pp. S44-S72.

D.R. Davis (1996), “Trade liberalization and income distribution,” NBER Working Paper No. 5693 (Cambridge, MA: August).

R.C. Feenstra and G.H. Hanson (1996), "Foreign investment, outsourcing, and relative wages," in R.C. Feenstra, G.M. Grossman and D.A. Irwin, eds., The Political Economy of Trade Policy: Papers in Honor of Jagdish Bhagwati (Cambridge, MA: MIT Press).

R. Findlay and S. Wellisz (1982), "Endogenous tariffs, the political economy of trade restrictions, and welfare," in J. Bhagwati, ed., Import Competition and Response (Chicago: The University of Chicago Press).

H. B. G. Ganzeboom and D. J. Treiman (1996), "Internationally comparable measures of occupational status for the 1988 International Standard Classification of Occupations," Social Science Research 25, pp. 201-239.

E. Gellner (1983), Nations and Nationalism (Oxford: Blackwell).

C. Graham and S. Pettinato (2001), "Happiness, markets, and democracy: Latin America in comparative perspective," Journal of Happiness Studies, forthcoming.

C. Graham and S. Pettinato (forthcoming), Happiness and Hardship: Opportunity and Insecurity in New Market Economies (Washington, D.C.: Brookings).

W.H. Greene (2000), Econometric Analysis (London: Prentice-Hall).

G.M. Grossman and E. Helpman (1994), "Protection for sale," American Economic Review 84, pp. 833-850.

G.H. Hanson and A.E. Harrison (1999), "Trade and wage inquality in Mexico," Industrial and Labor Relations Review 52, pp. 271-288. 
I.L.O. (1990), International Standard Classification of Occupations: ISCO-88 (International Labour Organization).

D.A. Irwin (1989), "Political economy and Peel's Repeal of the Corn Laws," Economics and Politics 1, pp. $41-59$.

D.A. Irwin (1994), "The political economy of free trade: voting in the British general election of 1906," Journal of Law and Economics 37, pp. 75-108.

W. Kaempfer and S. Marks (1993), "The expected effects of trade liberalization: evidence from U.S. Congressional action on fast-track authority," The World Economy 16, pp. 725-740.

R. Kanbur (1999), "Income distribution implications of globalization and liberalization in Africa," mimeo, Cornell University.

G. King, M. Tomz and J. Wittenberg (2000), "Making the most of statistical analyses: improving interpretation and presentation," American Journal of Political Science 44, pp. 341-355.

S.P. Magee (1978), "Three simple tests of the Stolper-Samuelson theorem," in P.Oppenheimer, ed., Issues in International Economics (Stockfield: Oriel Press).

S.P. Magee, WA. Brock and L. Young (1989), Black Hole Tariffs and Endogenous Policy Theory (Cambridge, UK: Cambridge University Press).

A.M. Mayda and D. Rodrik (2001), "Why are some people (and countries) more protectionist than others? A cross-country analysis," mimeo, Harvard University (March).

W. Mayer (1984), “Endogenous tariff formation,” American Economic Review 74, pp. 970-985.

D. Rodrik (1995), "Political economy of trade policy," in G.M. Grossman and K. Rogoff, eds., Handbook of International Economics Vol. 3 (Amsterdam: North Holland).

D. Rodrik (1997), Has Globalization Gone Too Far? (Washington DC: Institute for International Economics).

R. Rogowski (1989), Commerce and Coalitions: How Trade Affects Domestic Political Arrangements (Princeton, NJ: Princeton University Press).

K.F. Scheve and M.J. Slaughter (2001), "What determines individual trade-policy preferences?" Journal of International Economics 54, pp. 267-292.

C. Schonhardt-Bailey (1991), "Specific factors, capital markets, portfolio diversification, and free trade: domestic determinants of the Repeal of the Corn Laws," World Politics 43, pp. 545-569.

S. Shulman (2000), "Nationalist sources of international economic integration," International Studies Quarterly 44, pp. 365-390.

M. Slaughter (2000), "Trade and labor-market outcomes: what about developing countries?," paper presented to NBER Inter-American Seminar on Economics (July).

J. Svejnar (1999), "Labor markets in the transitional central and east European economies," in O. 
Ashenfelter and D. Card, eds., Handbook of Labor Economics, Volume 3 (Amsterdam: Elsevier).

B.G. Tabachnick, and L.S. Fidell (2001), Using Multivariate Statistics, Fourth Edition (Boston: Allyn and Bacon).

M. Tomz, J. Wittenberg and G. King (1999), "CLARIFY: Software for interpreting and presenting statistical results. Version 1.1.1.” Cambridge, MA: Harvard University, June 1.

http://gking.harvard.edu/

B. Wessels (1995), "Development of support: diffusion or demographic replacement," in O. Niedermayer and R. Sinnott, eds., Public Opinion and Internationalized Governance (Oxford: Oxford University Press).

A. Wood (1997), "Openness and wage inequality in developing countries: the Latin American challenge to East Asian conventional wisdom," World Bank Economic Review 11, pp. 33-57. 
Table 1: Factor analysis of nationalist items in ISSP National Identity Survey 1995

\begin{tabular}{lcc}
\hline & Factor 1 & Factor 2 \\
\hline [COUNTRY] better country than most other countries & 0.86 & 0.02 \\
World better place if people from other countries more like the & 0.78 & 0.2 \\
Rather be citizen of [COUNTRY] than of any other country in world & 0.61 & 0.29 \\
Impossible for people who do not share [NATNL.]traditions to be fully & -0.01 & 0.71 \\
People should support their country even if country is wrong & 0.20 & 0.63 \\
Importance of having been born in [COUNTRY] to be fully [NATIONALITY] & 0.16 & 0.63 \\
[COUNTRY] should follow own interests, even if conflicts with other nations & 0.23 & 0.55 \\
Percent variance & $\mathbf{2 6 . 3 4}$ & $\mathbf{2 4 . 5 0}$ \\
\hline
\end{tabular}

Extraction Method: Principal Component Analysis. Rotation Method: Varimax with Kaiser Normalization.

Source: Data from ISSP National Identity Survey 1995 
Table 2. Summary statistics, selected variables

\begin{tabular}{|c|c|c|c|c|c|c|c|}
\hline Country & Variable & Protect & Patriotism & Chauvinism & Skill & Nat.mobility & Int.mobility \\
\hline Australia & Obs & 2398 & 2398 & 2339 & 2181 & 2407 & 2404 \\
\hline Australia & Mean & 3.997 & 3.956 & 2.952 & 2.934 & 0.619 & 0.204 \\
\hline Australia & Std.dev. & 0.988 & 0.677 & 0.862 & 1.262 & 0.486 & 0.403 \\
\hline W.Germany & Obs & 1255 & 1248 & 1234 & 709 & 1171 & 1193 \\
\hline W. Germany & Mean & 3.083 & 3.089 & 2.672 & 2.677 & 0.638 & 0.220 \\
\hline W. Germany & Std.dev. & 1.232 & 0.922 & 0.960 & 1.074 & 0.481 & 0.415 \\
\hline E. Germany & Obs & 604 & 596 & 589 & 306 & 569 & 577 \\
\hline E. Germany & Mean & 3.563 & 3.136 & 2.818 & 2.699 & 0.571 & 0.125 \\
\hline E. Germany & Std.dev. & 1.189 & 0.900 & 0.957 & 1.063 & 0.495 & 0.331 \\
\hline Britain & Obs & 1043 & 1029 & 1016 & 1006 & 974 & 982 \\
\hline Britain & Mean & 3.723 & 3.535 & 3.322 & 2.613 & 0.574 & 0.231 \\
\hline Britain & Std.dev. & 1.004 & 0.817 & 0.830 & 1.174 & 0.495 & 0.422 \\
\hline USA & Obs & 1343 & 1348 & 1281 & 1300 & 1336 & 1340 \\
\hline USA & Mean & 3.707 & 3.972 & 3.113 & 2.746 & 0.738 & 0.166 \\
\hline USA & Std.dev. & 1.016 & 0.705 & 0.841 & 1.204 & 0.440 & 0.373 \\
\hline Austria & Obs & 1007 & 1007 & 1007 & 505 & 1007 & 1007 \\
\hline Austria & Mean & 3.873 & 3.871 & 3.422 & 2.638 & 0.393 & 0.127 \\
\hline Austria & Std.dev. & 1.163 & 0.820 & 0.888 & 1.256 & 0.489 & 0.333 \\
\hline Hungary & Obs & 998 & 995 & 996 & 913 & 997 & 1000 \\
\hline Hungary & Mean & 4.047 & 3.285 & 3.430 & 2.318 & 0.311 & 0.094 \\
\hline Hungary & Std.dev. & 1.075 & 0.779 & 0.805 & 1.082 & 0.463 & 0.292 \\
\hline Italy & Obs & 1093 & 1090 & 1090 & 0 & 1091 & 1094 \\
\hline Italy & Mean & 3.571 & 3.067 & 3.112 & & 0.630 & 0.224 \\
\hline Italy & Std.dev. & 1.216 & 0.873 & 0.778 & & 0.483 & 0.417 \\
\hline Ireland & Obs & 991 & 994 & 988 & 908 & 987 & 986 \\
\hline Ireland & Mean & 3.650 & 3.729 & 3.342 & 2.439 & 0.421 & 0.173 \\
\hline Ireland & Std.dev. & 1.128 & 0.684 & 0.709 & 1.171 & 0.494 & 0.379 \\
\hline Netherlands & Obs & 2071 & 2070 & 2052 & 1702 & 2035 & 2048 \\
\hline Netherlands & Mean & 2.912 & 3.065 & 2.881 & 2.791 & 0.639 & 0.250 \\
\hline Netherlands & Std.dev. & 0.992 & 0.789 & 0.812 & 1.018 & 0.480 & 0.433 \\
\hline Norway & Obs & 1494 & 1492 & 1458 & 1280 & 1485 & 1491 \\
\hline Norway & Mean & 3.144 & 3.537 & 3.144 & 2.665 & 0.602 & 0.192 \\
\hline Norway & Std.dev. & 1.038 & 0.739 & 0.846 & 1.121 & 0.490 & 0.394 \\
\hline Sweden & Obs & 1284 & 1274 & 1265 & 0 & 1245 & 1265 \\
\hline Sweden & Mean & 3.228 & 3.290 & 3.042 & & 0.590 & 0.288 \\
\hline Sweden & Std.dev. & 1.081 & 0.800 & 0.869 & & 0.492 & 0.453 \\
\hline Czech Rep. & Obs & 1109 & 1111 & 1099 & 970 & 1068 & 1104 \\
\hline Czech Rep. & Mean & 3.415 & 3.110 & 3.129 & 2.533 & 0.488 & 0.121 \\
\hline Czech Rep. & Std.dev. & 1.294 & 0.806 & 0.817 & 1.041 & 0.500 & 0.327 \\
\hline Slovenia & Obs & 1036 & 1035 & 1035 & 823 & 1036 & 1036 \\
\hline Slovenia & Mean & 3.465 & 3.229 & 3.292 & 2.350 & 0.378 & 0.125 \\
\hline Slovenia & Std.dev. & 1.174 & 0.792 & 0.791 & 0.992 & 0.485 & 0.330 \\
\hline Poland & Obs & 1582 & 1573 & 1556 & 1454 & 1094 & 1564 \\
\hline Poland & Mean & 3.787 & 3.456 & 3.458 & 2.221 & 0.441 & 0.187 \\
\hline Poland & Std.dev. & 1.083 & 0.731 & 0.714 & 0.914 & 0.497 & 0.390 \\
\hline Bulgaria & Obs & 1102 & 1098 & 1095 & 996 & 1097 & 1099 \\
\hline Bulgaria & Mean & 4.190 & 3.582 & 3.998 & 2.228 & 0.418 & 0.257 \\
\hline Bulgaria & Std.dev. & 1.090 & 0.865 & 0.750 & 1.130 & 0.493 & 0.437 \\
\hline Russia & Obs & 1585 & 1585 & 1585 & 807 & 1585 & 1585 \\
\hline Russia & Mean & 3.670 & 3.297 & 3.517 & 2.530 & 0.218 & 0.107 \\
\hline Russia & Std.dev. & 1.282 & 0.831 & 0.805 & 1.067 & 0.413 & 0.310 \\
\hline New Zealand & Obs & 1019 & 1015 & 996 & 633 & 1018 & 1021 \\
\hline New Zealand & Mean & 3.406 & 3.798 & 3.060 & 2.866 & 0.623 & 0.245 \\
\hline New Zealand & Std.dev. & 1.147 & 0.693 & 0.798 & 1.263 & 0.485 & 0.430 \\
\hline Canada & Obs & 1525 & 1527 & 1496 & 923 & 1519 & 1519 \\
\hline Canada & Mean & 3.264 & 3.831 & 2.707 & 3.115 & 0.722 & 0.286 \\
\hline Canada & Std.dev. & 1.135 & 0.823 & 0.809 & 0.963 & 0.448 & 0.452 \\
\hline Phillippines & Obs & 1200 & 1200 & 1198 & 633 & 1200 & 1200 \\
\hline Phillippines & Mean & 3.624 & 3.613 & 3.430 & 1.790 & 0.469 & 0.279 \\
\hline Phillippines & Std.dev. & 0.918 & 0.633 & 0.564 & 0.897 & 0.499 & 0.449 \\
\hline Japan & Obs & 1252 & 1252 & 1247 & 0 & 1256 & 1256 \\
\hline Japan & Mean & 2.919 & 3.931 & 2.890 & & 0.318 & 0.076 \\
\hline Japan & Std.dev. & 1.282 & 0.740 & 0.950 & & 0.466 & 0.265 \\
\hline Estonia & Obs & 1221 & 1221 & 1221 & 0 & 1221 & 1221 \\
\hline Estonia & Mean & 3.813 & 3.260 & 3.362 & & 0.498 & 0.215 \\
\hline Estonia & Std.dev. & 0.906 & 0.760 & 0.692 & & 0.500 & 0.411 \\
\hline Latvia & Obs & 1041 & 1026 & 1026 & 434 & 1027 & 1035 \\
\hline Latvia & Mean & 4.042 & 3.146 & 3.252 & 2.816 & 0.251 & 0.135 \\
\hline Latvia & Std.dev. & 1.180 & 0.831 & 0.828 & 1.136 & 0.434 & 0.342 \\
\hline Slovakia & Obs & 1388 & 1388 & 1388 & 1222 & 1359 & 1388 \\
\hline Slovakia & Mean & 3.488 & 3.029 & 2.851 & 2.265 & 0.531 & 0.241 \\
\hline Slovakia & Std.dev. & 1.273 & 0.906 & 0.926 & 0.982 & 0.499 & 0.428 \\
\hline
\end{tabular}


Table 3. Cross-country correlations

(country averages)

\begin{tabular}{|c|c|c|c|c|c|c|c|}
\hline & Protect & Patriotism & $\begin{array}{c}\text { Chauvinis } \\
\mathrm{m}\end{array}$ & Skill & Nat.mobility & Int.mobility & $\begin{array}{c}\text { GDP per } \\
\text { capita }\end{array}$ \\
\hline Protect & 1.000 & & & & & & \\
\hline Patriotism & 0.127 & 1.000 & & & & & \\
\hline Chauvinism & 0.691 & 0.105 & 1.000 & & & & \\
\hline Skill & -0.271 & 0.223 & -0.590 & 1.000 & & & \\
\hline Nat. mobility & -0.376 & 0.126 & -0.572 & 0.468 & 1.000 & & \\
\hline Int.mobility & -0.151 & 0.012 & -0.120 & 0.003 & 0.633 & 1.000 & \\
\hline GDP per capita & -0.482 & 0.383 & -0.582 & 0.672 & 0.664 & 0.080 & 1.000 \\
\hline
\end{tabular}

Source: see text. 
Table 4. Exploratory regressions: ordered probit

Dependent variable is protect. Country dummy coefficients not reported

\begin{tabular}{|c|c|c|c|c|c|c|c|c|c|}
\hline Equation & (1) & (2) & (3) & (4) & $(5)$ & (6) & (7) & $(8)$ & (9) \\
\hline Country dummies? & $\overline{\text { Yes }}$ & $\overline{\text { Yes }}$ & Yes & $\overline{\text { Yes }}$ & $\overline{\text { Yes }}$ & $\overline{\text { Yes }}$ & $\overline{\text { Yes }}$ & No & $\overline{\text { Yes }}$ \\
\hline GDPCAP & & & & & & & & $\begin{array}{c}-0.0163 \\
(-13.2)\end{array}$ & $\begin{array}{r}0.0034 \\
(1.47)\end{array}$ \\
\hline Patriotism & & $\begin{array}{l}0.1946 \\
(20.35)\end{array}$ & $\begin{array}{l}0.1722 \\
(17.34)\end{array}$ & $\begin{array}{l}0.1750 \\
(17.14)\end{array}$ & $\begin{array}{l}0.1734 \\
(12.55)\end{array}$ & $\begin{array}{l}0.1864 \\
(14.05)\end{array}$ & $\begin{array}{l}0.1527 \\
(11.34)\end{array}$ & $\begin{array}{l}0.2077 \\
(22.04)\end{array}$ & $\begin{array}{l}0.1750 \\
(17.14)\end{array}$ \\
\hline Chauvinism & & $\begin{array}{l}0.3369 \\
(36.45)\end{array}$ & $\begin{array}{r}0.3293 \\
(34.8)\end{array}$ & $\begin{array}{l}0.3301 \\
(33.85)\end{array}$ & $\begin{array}{r}0.3183 \\
(23.7)\end{array}$ & $\begin{array}{l}0.3594 \\
(28.96)\end{array}$ & $\begin{array}{l}0.3176 \\
(23.43)\end{array}$ & $\begin{array}{l}0.3382 \\
(36.27)\end{array}$ & $\begin{array}{l}0.3301 \\
(33.85)\end{array}$ \\
\hline Skill345 & $\begin{array}{r}-0.0816 \\
(-2.16)\end{array}$ & $\begin{array}{r}-0.0169 \\
(-0.44)\end{array}$ & $\begin{array}{r}0.0070 \\
(0.18)\end{array}$ & $\begin{array}{r}-0.0204 \\
(-0.51)\end{array}$ & $\begin{array}{r}-0.0913 \\
(-1.81)\end{array}$ & $\begin{array}{r}-0.0713 \\
(-1.28)\end{array}$ & $\begin{array}{r}0.0558 \\
(1.04)\end{array}$ & $\begin{array}{r}-0.0353 \\
(-0.92)\end{array}$ & $\begin{array}{r}-0.0204 \\
(-0.51)\end{array}$ \\
\hline Skill345*GDPCAP & $\begin{array}{c}-0.0137 \\
(-6.36)\end{array}$ & $\begin{array}{r}-0.0104 \\
(-4.75)\end{array}$ & $\begin{array}{r}-0.0109 \\
(-4.88)\end{array}$ & $\begin{array}{r}-0.0095 \\
(-4.16)\end{array}$ & $\begin{array}{r}-0.0055 \\
(-1.74)\end{array}$ & $\begin{array}{r}-0.0074 \\
(-2.50)\end{array}$ & $\begin{array}{r}-0.0115 \\
(-3.30)\end{array}$ & $\begin{array}{c}-0.0039 \\
(-1.80)\end{array}$ & $\begin{array}{r}-0.0095 \\
(-4.16)\end{array}$ \\
\hline National mobility & & & $\begin{array}{r}-0.0174 \\
(-1.18)\end{array}$ & $\begin{array}{r}-0.0048 \\
(-0.31)\end{array}$ & $\begin{array}{c}0.0181 \\
(0.86)\end{array}$ & $\begin{array}{r}-0.0113 \\
(-0.56)\end{array}$ & $\begin{array}{r}0.0095 \\
(0.45)\end{array}$ & $\begin{array}{r}0.0313 \\
(2.05)\end{array}$ & $\begin{array}{r}-0.0048 \\
(-0.31)\end{array}$ \\
\hline International mobility & & & $\begin{array}{r}-0.1325 \\
(-7.22)\end{array}$ & $\begin{array}{c}-0.1179 \\
(-6.2)\end{array}$ & $\begin{array}{r}-0.1174 \\
(-4.68)\end{array}$ & $\begin{array}{r}-0.1218 \\
(-4.97)\end{array}$ & $\begin{array}{r}-0.0890 \\
(-3.47)\end{array}$ & $\begin{array}{r}-0.1025 \\
(-5.46)\end{array}$ & $\begin{array}{c}-0.1179 \\
(-6.2)\end{array}$ \\
\hline Never lived abroad & & & $\begin{array}{r}0.1132 \\
(6.35)\end{array}$ & $\begin{array}{r}0.1043 \\
(5.64)\end{array}$ & $\begin{array}{r}0.1141 \\
(4.67)\end{array}$ & $\begin{array}{r}0.1015 \\
(4.46)\end{array}$ & $\begin{array}{c}0.0848 \\
(3.29)\end{array}$ & $\begin{array}{r}0.0234 \\
(1.31)\end{array}$ & $\begin{array}{r}0.1043 \\
(5.64)\end{array}$ \\
\hline Age & & & & $\begin{array}{r}0.0014 \\
(2.98)\end{array}$ & $\begin{array}{r}0.0027 \\
(3.51)\end{array}$ & $\begin{array}{r}0.0022 \\
(3.55)\end{array}$ & $\begin{array}{r}0.0008 \\
(1.21)\end{array}$ & $\begin{array}{r}0.0022 \\
(4.72)\end{array}$ & $\begin{array}{r}0.0014 \\
(2.98)\end{array}$ \\
\hline Woman & & & & $\begin{array}{l}0.2222 \\
(15.96)\end{array}$ & $\begin{array}{l}0.2243 \\
(11.66)\end{array}$ & $\begin{array}{l}0.2592 \\
(14.48)\end{array}$ & $\begin{array}{r}0.1863 \\
(9.72)\end{array}$ & $\begin{array}{l}0.2251 \\
(16.31)\end{array}$ & $\begin{array}{l}0.2222 \\
(15.96)\end{array}$ \\
\hline Married & & & & $\begin{array}{r}0.0333 \\
(2.24)\end{array}$ & $\begin{array}{r}0.0002 \\
(0.01)\end{array}$ & $\begin{array}{r}0.0233 \\
(1.21)\end{array}$ & $\begin{array}{r}0.0446 \\
(2.23)\end{array}$ & $\begin{array}{r}0.0156 \\
(1.07)\end{array}$ & $\begin{array}{r}0.0333 \\
(2.24)\end{array}$ \\
\hline Catholic & & & & $\begin{array}{r}0.0667 \\
(3.36)\end{array}$ & $\begin{array}{r}0.0469 \\
(1.72)\end{array}$ & $\begin{array}{r}0.0652 \\
(2.66)\end{array}$ & $\begin{array}{r}0.1155 \\
(4.47)\end{array}$ & $\begin{array}{r}0.1302 \\
(9.06)\end{array}$ & $\begin{array}{r}0.0667 \\
(3.36)\end{array}$ \\
\hline Rural & & & & & $\begin{array}{r}0.1326 \\
(5.84)\end{array}$ & & & & \\
\hline Unemployed & & & & & $\begin{array}{r}0.0653 \\
(1.12)\end{array}$ & & & & \\
\hline Public sector & & & & & $\begin{array}{r}0.0363 \\
(1.58)\end{array}$ & & & & \\
\hline Self-employed & & & & & $\begin{array}{r}-0.0834 \\
(-2.76)\end{array}$ & & & & \\
\hline Trade union & & & & & $\begin{array}{r}0.0074 \\
(1.62)\end{array}$ & & & & \\
\hline Right-wing & & & & & & $\begin{array}{r}-0.0706 \\
(-7.47)\end{array}$ & & & \\
\hline Familiar with regional association (RA) & & & & & & & $\begin{array}{r}-0.0239 \\
(-1.17)\end{array}$ & & \\
\hline No benefit from RA & & & & & & & $\begin{array}{r}0.1364 \\
(8.97)\end{array}$ & & \\
\hline Stay independent from RA & & & & & & & $\begin{array}{r}0.0883 \\
(6.15) \\
\end{array}$ & & \\
\hline Cut1 & -1.7205 & -0.2570 & -0.2796 & -0.0497 & -0.2597 & -0.2467 & 0.2368 & 0.0086 & 0.0260 \\
\hline Cut2 & -0.8396 & 0.6801 & 0.6610 & 0.9021 & 0.7886 & 0.7804 & 1.1959 & 0.9344 & 0.9258 \\
\hline Cut3 & -0.1743 & 1.3880 & 1.3734 & 1.6196 & 1.4807 & 1.4728 & 1.8647 & 1.6238 & 1.6433 \\
\hline Cut4 & 0.7632 & 2.3855 & 2.3719 & 2.6212 & 2.5015 & 2.5335 & 2.8431 & 2.5851 & 2.6449 \\
\hline No. obs. & 26827 & 26365 & 25273 & 24278 & 13009 & 14737 & 13282 & 24278 & 24278 \\
\hline LR chi2 & 3258.61 & 6151 & 6038.6 & 6065.92 & 3116.12 & 4320.99 & 3483.05 & 4488.98 & 6065.92 \\
\hline Prob $>$ chi 2 & 0 & 0 & 0 & 0 & 0 & 0 & 0 & 0 & 0 \\
\hline Pseudo R2 & 0.0407 & 0.0781 & 0.0799 & 0.0835 & 0.0804 & 0.0979 & 0.0873 & 0.0618 & 0.0835 \\
\hline Loglikelihood & -38412.2 & -36294.3 & -34784.6 & -33281.2 & -17815.5 & -19904.5 & -18216.6 & -34069.7 & -33281.2 \\
\hline
\end{tabular}

Source: see text. T-statistics are in parentheses. 
Table 5. Different specifications of skill

Dependent variable is protect. Country dummies included (coefficients not reported)

\begin{tabular}{|c|c|c|}
\hline Variable & (1) & (2) \\
\hline Patriotism & $\begin{array}{c}0.175 \\
(17.16)\end{array}$ & $\begin{array}{c}0.175 \\
(17.12)\end{array}$ \\
\hline Chauvinism & $\begin{array}{c}0.329 \\
(33.73)\end{array}$ & $\begin{array}{c}0.331 \\
(33.92)\end{array}$ \\
\hline Skill1 & $\begin{array}{l}-0.162 \\
(-1.90)\end{array}$ & \\
\hline Skill1*GDPCAP & $\begin{array}{c}0.0136 \\
(2.67)\end{array}$ & \\
\hline Skill2 & $\begin{array}{l}-0.068 \\
(-0.90)\end{array}$ & \\
\hline Skill2*GDPCAP & $\begin{array}{r}0.0087 \\
(2.02)\end{array}$ & \\
\hline Skill3 & $\begin{array}{l}-0.019 \\
(-0.21)\end{array}$ & \\
\hline Skill3*GDPCAP & $\begin{array}{c}-0.0031 \\
(-0.63)\end{array}$ & \\
\hline Skill4 & $\begin{array}{l}-0.098 \\
(-1.12)\end{array}$ & \\
\hline Skill4*GDPCAP & $\begin{array}{r}-0.0017 \\
(-0.36)\end{array}$ & \\
\hline Skill5 & $\begin{array}{l}-0.300 \\
(-2.80)\end{array}$ & \\
\hline Skill5*GDPCAP & $\begin{array}{r}0.0056 \\
(0.96)\end{array}$ & \\
\hline Skill345*DWEST & & $\begin{array}{l}-0.212 \\
(-9.99)\end{array}$ \\
\hline Skill345*DEAST & & $\begin{array}{l}-0.104 \\
(-3.80)\end{array}$ \\
\hline Skill345*DPHILLIPPINES & & $\begin{array}{l}-0.013 \\
(-0.09)\end{array}$ \\
\hline National mobility & $\begin{array}{l}-0.005 \\
(-0.35)\end{array}$ & $\begin{array}{l}-0.005 \\
(-0.33)\end{array}$ \\
\hline International mobility & $\begin{array}{l}-0.117 \\
(-6.16)\end{array}$ & $\begin{array}{l}-0.118 \\
(-6.20)\end{array}$ \\
\hline Never lived abroad & $\begin{array}{l}0.102 \\
(5.50)\end{array}$ & $\begin{array}{l}0.104 \\
(5.61)\end{array}$ \\
\hline Age & $\begin{array}{l}0.002 \\
(3.37)\end{array}$ & $\begin{array}{l}0.001 \\
(2.90)\end{array}$ \\
\hline Woman & $\begin{array}{c}0.220 \\
(15.69)\end{array}$ & $\begin{array}{c}0.222 \\
(15.97)\end{array}$ \\
\hline Married & $\begin{array}{l}0.031 \\
(2.07)\end{array}$ & $\begin{array}{l}0.033 \\
(2.25)\end{array}$ \\
\hline Catholic & $\begin{array}{l}0.065 \\
(3.29)\end{array}$ & $\begin{array}{l}0.067 \\
(3.36)\end{array}$ \\
\hline Cut1 & -0.063 & -0.055 \\
\hline Cut2 & 0.890 & 0.897 \\
\hline Cut3 & 1.608 & 1.615 \\
\hline Cut4 & 2.610 & 2.616 \\
\hline Number of obs & 24278.000 & 24278.000 \\
\hline LR chi2 & 6097.800 & 6059.440 \\
\hline Prob > chi2 2 & 0.000 & 0.000 \\
\hline Pseudo R2 & 0.084 & 0.083 \\
\hline$\underline{\text { Log likelihood }}$ & -33265.257 & -33284.436 \\
\hline
\end{tabular}

Source: see text. T-statistics are in parentheses. 
Table 6. Country-specific models

Dependent variable is protect.

\begin{tabular}{|c|c|c|c|c|c|c|c|c|}
\hline & Australia & $\begin{array}{c}\text { W.German } \\
y\end{array}$ & $\begin{array}{c}\text { E.German } \\
y\end{array}$ & Britain & $\overline{\mathrm{USA}}$ & Austria & Hungary & Italy \\
\hline Patriotism & $\begin{array}{l}0.240 \\
(5.63)\end{array}$ & $\begin{array}{l}0.128 \\
(2.07)\end{array}$ & $\begin{array}{l}0.246 \\
(2.52)\end{array}$ & $\begin{array}{l}0.159 \\
(2.78)\end{array}$ & $\begin{array}{l}0.286 \\
(5.39)\end{array}$ & $\begin{array}{l}0.057 \\
(1.09)\end{array}$ & $\begin{array}{l}0.053 \\
(0.98)\end{array}$ & $\begin{array}{l}0.174 \\
(3.91)\end{array}$ \\
\hline Chauvinism & $\begin{array}{l}0.344 \\
(9.76)\end{array}$ & $\begin{array}{l}0.425 \\
(7.12)\end{array}$ & $\begin{array}{l}0.433 \\
(4.85)\end{array}$ & $\begin{array}{l}0.510 \\
(9.18)\end{array}$ & $\begin{array}{l}0.419 \\
(9.54)\end{array}$ & $\begin{array}{l}0.454 \\
(8.97)\end{array}$ & $\begin{array}{l}0.225 \\
(4.62)\end{array}$ & $\begin{array}{l}0.299 \\
(6.01)\end{array}$ \\
\hline Skill345 & $\begin{array}{l}-0.216 \\
(-4.04)\end{array}$ & $\begin{array}{l}-0.318 \\
(-3.59)\end{array}$ & $\begin{array}{l}-0.191 \\
(-1.40)\end{array}$ & $\begin{array}{l}-0.352 \\
(-4.38)\end{array}$ & $\begin{array}{l}-0.300 \\
(-4.58)\end{array}$ & $\begin{array}{l}-0.201 \\
(-2.20)\end{array}$ & $\begin{array}{l}-0.035 \\
(-0.41)\end{array}$ & \\
\hline National mobility & $\begin{array}{l}0.029 \\
(0.51)\end{array}$ & $\begin{array}{l}-0.215 \\
(-2.23)\end{array}$ & $\begin{array}{l}-0.338 \\
(-2.38)\end{array}$ & $\begin{array}{l}0.089 \\
(1.08)\end{array}$ & $\begin{array}{l}0.056 \\
(0.74)\end{array}$ & $\begin{array}{l}-0.158 \\
(-1.94)\end{array}$ & $\begin{array}{l}-0.052 \\
(-0.62)\end{array}$ & $\begin{array}{l}0.069 \\
(0.94)\end{array}$ \\
\hline International mobility & $\begin{array}{l}-0.119 \\
(-1.76)\end{array}$ & $\begin{array}{l}-0.187 \\
(-1.77)\end{array}$ & $\begin{array}{l}-0.123 \\
(-0.63)\end{array}$ & $\begin{array}{l}-0.124 \\
(-1.28)\end{array}$ & $\begin{array}{l}0.001 \\
(0.01)\end{array}$ & $\begin{array}{l}-0.154 \\
(-1.33)\end{array}$ & $\begin{array}{l}-0.160 \\
(-1.22)\end{array}$ & $\begin{array}{l}-0.027 \\
(-0.31)\end{array}$ \\
\hline Never lived abroad & $\begin{array}{l}0.102 \\
(1.81)\end{array}$ & $\begin{array}{l}0.188 \\
(1.66)\end{array}$ & $\begin{array}{l}0.443 \\
(1.47)\end{array}$ & $\begin{array}{l}0.073 \\
(0.84)\end{array}$ & $\begin{array}{l}0.099 \\
(1.31)\end{array}$ & $\begin{array}{l}0.174 \\
(1.77)\end{array}$ & $\begin{array}{l}-0.103 \\
(-0.73)\end{array}$ & $\begin{array}{l}0.271 \\
(2.64)\end{array}$ \\
\hline Age & $\begin{array}{c}0.003 \\
(1.66)\end{array}$ & $\begin{array}{l}-0.002 \\
(-0.37)\end{array}$ & $\begin{array}{l}-0.013 \\
(-1.96)\end{array}$ & $\begin{array}{c}0.003 \\
(1.08)\end{array}$ & $\begin{array}{c}0.002 \\
(1.18)\end{array}$ & $\begin{array}{l}-0.003 \\
(-1.38)\end{array}$ & $\begin{array}{l}0.005 \\
(1.90)\end{array}$ & $\begin{array}{l}0.000 \\
(0.19)\end{array}$ \\
\hline Woman & $\begin{array}{l}0.333 \\
(6.29)\end{array}$ & $\begin{array}{l}0.405 \\
(4.53)\end{array}$ & $\begin{array}{l}0.680 \\
(5.06)\end{array}$ & $\begin{array}{l}0.191 \\
(2.54)\end{array}$ & $\begin{array}{l}0.155 \\
(2.44)\end{array}$ & $\begin{array}{l}0.311 \\
(4.34)\end{array}$ & $\begin{array}{l}0.074 \\
(0.98)\end{array}$ & $\begin{array}{l}0.215 \\
(3.28)\end{array}$ \\
\hline Married & $\begin{array}{l}-0.060 \\
(-0.99)\end{array}$ & $\begin{array}{l}-0.199 \\
(-2.06)\end{array}$ & $\begin{array}{l}0.125 \\
(0.82)\end{array}$ & $\begin{array}{l}0.005 \\
(0.07)\end{array}$ & $\begin{array}{l}0.113 \\
(1.79)\end{array}$ & $\begin{array}{l}0.180 \\
(2.44)\end{array}$ & $\begin{array}{l}0.010 \\
(0.14)\end{array}$ & $\begin{array}{l}0.152 \\
(2.09)\end{array}$ \\
\hline Catholic & $\begin{array}{r}0.083 \\
(1.33) \\
\end{array}$ & $\begin{array}{l}0.014 \\
(0.16) \\
\end{array}$ & $\begin{array}{l}-0.166 \\
(-0.46) \\
\end{array}$ & $\begin{array}{r}0.077 \\
(0.61) \\
\end{array}$ & $\begin{array}{l}-0.031 \\
(-0.42) \\
\end{array}$ & $\begin{array}{l}-0.076 \\
(-0.83) \\
\end{array}$ & $\begin{array}{l}-0.033 \\
(-0.42) \\
\end{array}$ & $\begin{array}{l}-0.130 \\
(-0.84) \\
\end{array}$ \\
\hline$\overline{\text { Cut1 }}$ & -0.321 & -0.177 & 0.047 & -0.100 & 0.529 & -0.173 & -0.961 & 0.228 \\
\hline Cut2 & 0.863 & 0.971 & 1.255 & 1.228 & 1.431 & 0.750 & -0.291 & 1.050 \\
\hline Cut3 & 1.401 & 1.728 & 1.912 & 2.040 & 2.223 & 1.267 & 0.468 & 1.567 \\
\hline Cut4 & 2.679 & 2.716 & 2.888 & 3.325 & 3.546 & 2.226 & 1.172 & 2.535 \\
\hline Number of obs & 1827 & 648 & 285 & 906 & 1225 & 985 & 930 & 1084 \\
\hline LR chi2 & 313.120 & 179.890 & 104.600 & 243.020 & 276.110 & 226.380 & 50.160 & 124.830 \\
\hline Prob $>$ chi 2 & 0.000 & 0.000 & 0.000 & 0.000 & 0.000 & 0.000 & 0.000 & 0.000 \\
\hline Pseudo R2 & 0.067 & 0.091 & 0.120 & 0.098 & 0.083 & 0.083 & 0.021 & 0.039 \\
\hline Log likelihood & -2164.910 & -899.460 & -385.137 & -1113.125 & -1535.116 & -1255.603 & -1188.651 & -1553.800 \\
\hline
\end{tabular}

Source: see text. T-statistics are in parentheses. 
Table 6. (Continued)

Dependent variable is protect.

\begin{tabular}{|c|c|c|c|c|c|c|c|c|}
\hline Variable & Ireland & $\begin{array}{c}\text { Netherland } \\
\text { s }\end{array}$ & Norway & Sweden & Czech. Rep. & Slovenia & Poland & Bulgaria \\
\hline \multirow[t]{2}{*}{ Patriotism } & 0.197 & 0.073 & 0.218 & 0.337 & 0.154 & 0.254 & 0.171 & 0.103 \\
\hline & $(3.33)$ & $(2.01)$ & $(4.51)$ & $(7.26)$ & $(3.12)$ & $(4.59)$ & $(2.94)$ & $(2.14)$ \\
\hline \multirow[t]{2}{*}{ Chauvinism } & 0.335 & 0.480 & 0.281 & 0.352 & 0.318 & 0.357 & 0.231 & 0.397 \\
\hline & $(5.63)$ & $(12.71)$ & $(6.83)$ & (8.39) & $(6.82)$ & $(6.57)$ & (3.99) & $(7.41)$ \\
\hline \multirow[t]{2}{*}{ Skill345 } & -0.233 & -0.170 & -0.217 & & -0.212 & -0.407 & -0.009 & 0.128 \\
\hline & $(-2.81)$ & $(-3.19)$ & $(-3.56)$ & & $(-2.85)$ & $(-4.97)$ & $(-0.11)$ & $(1.50)$ \\
\hline \multirow[t]{2}{*}{ National mobility } & -0.038 & -0.036 & -0.098 & -0.113 & -0.068 & -0.090 & -0.009 & 0.017 \\
\hline & $(-0.44)$ & $(-0.65)$ & $(-1.52)$ & $(-1.62)$ & $(-0.94)$ & $(-1.09)$ & $(-0.11)$ & $(0.21)$ \\
\hline \multirow[t]{2}{*}{ International mobility } & -0.110 & -0.087 & -0.281 & -0.275 & -0.125 & -0.109 & -0.034 & -0.219 \\
\hline & $(-1.01)$ & $(-1.35)$ & $(-3.43)$ & $(-3.45)$ & $(-1.10)$ & $(-0.90)$ & $(-0.35)$ & $(-2.29)$ \\
\hline \multirow[t]{2}{*}{ Never lived abroad } & 0.139 & 0.123 & 0.160 & 0.135 & 0.034 & 0.069 & 0.142 & 0.161 \\
\hline & $(1.72)$ & $(1.78)$ & $(2.21)$ & $(1.79)$ & $(0.33)$ & $(0.77)$ & $(1.29)$ & $(1.43)$ \\
\hline \multirow[t]{2}{*}{ Age } & -0.002 & 0.001 & 0.000 & 0.006 & 0.010 & -0.001 & -0.005 & 0.002 \\
\hline & $(-0.88)$ & $(0.69)$ & $(-0.16)$ & $(2.68)$ & $(4.23)$ & $(-0.21)$ & $(-2.11)$ & $(0.87)$ \\
\hline \multirow[t]{2}{*}{ Woman } & 0.371 & 0.335 & 0.235 & 0.506 & 0.217 & 0.109 & 0.034 & 0.019 \\
\hline & $(4.96)$ & $(6.59)$ & (4.11) & $(8.00)$ & $(3.17)$ & $(1.48)$ & $(0.47)$ & $(0.27)$ \\
\hline \multirow[t]{2}{*}{ Married } & -0.035 & 0.111 & 0.038 & -0.070 & 0.032 & -0.082 & -0.102 & 0.139 \\
\hline & $(-0.45)$ & $(2.07)$ & $(0.59)$ & $(-1.02)$ & $(0.44)$ & $(-0.97)$ & $(-1.30)$ & $(1.74)$ \\
\hline \multirow[t]{2}{*}{ Catholic } & 0.051 & 0.061 & -0.923 & -0.164 & 0.095 & 0.064 & 0.057 & -0.573 \\
\hline & $(0.35)$ & $(0.95)$ & $(-2.27)$ & $(-0.46)$ & $(1.32)$ & $(0.72)$ & $(0.54)$ & $(-0.97)$ \\
\hline Cut1 & -0.149 & 0.097 & -0.150 & 0.783 & 0.563 & -0.071 & -0.724 & 0.454 \\
\hline Cut2 & 1.147 & 1.551 & 1.072 & 1.769 & 1.315 & 1.171 & 0.198 & 0.750 \\
\hline Cut3 & 1.510 & 2.503 & 2.050 & 2.885 & 1.929 & 1.873 & 0.894 & 1.445 \\
\hline Cut4 & 2.679 & 3.794 & 3.228 & 3.990 & 2.709 & 2.702 & 1.838 & 2.181 \\
\hline Number of obs & 866 & 1827 & 1391 & 1186 & 994 & 876 & 951 & 1050 \\
\hline LR chi2 & 126.500 & 372.290 & 263.010 & 383.120 & 177.000 & 186.410 & 58.420 & 132.090 \\
\hline Prob $>$ chi 2 & 0.000 & 0.000 & 0.000 & 0.000 & 0.000 & 0.000 & 0.000 & 0.000 \\
\hline Pseudo R2 & 0.053 & 0.074 & 0.067 & 0.110 & 0.057 & 0.071 & 0.022 & 0.053 \\
\hline Log likelihood & -1133.695 & -2325.767 & -1845.643 & -1547.066 & -1461.511 & $-1214.625-$ & 1320.243 & -1192.092 \\
\hline
\end{tabular}

Source: see text. T-statistics are in parentheses. 
Table 6. (Continued)

Dependent variable is protect.

\begin{tabular}{|c|c|c|c|c|c|c|c|c|}
\hline & Russia & New Zealand & Canada & $\begin{array}{c}\text { Phillippine } \\
\text { S }\end{array}$ & Japan & Estonia & Latvia & Slovakia \\
\hline Patriotism & $\begin{array}{l}0.201 \\
(3.96)\end{array}$ & $\begin{array}{l}0.120 \\
(2.12)\end{array}$ & $\begin{array}{l}0.117 \\
(2.24)\end{array}$ & $\begin{array}{l}0.127 \\
(1.79)\end{array}$ & $\begin{array}{l}0.142 \\
(2.96)\end{array}$ & $\begin{array}{l}0.135 \\
(2.67)\end{array}$ & $\begin{array}{l}0.140 \\
(1.90)\end{array}$ & $\begin{array}{l}0.288 \\
(6.94)\end{array}$ \\
\hline Chauvinism & $\begin{array}{l}0.323 \\
(6.31)\end{array}$ & $\begin{array}{l}0.400 \\
(8.05)\end{array}$ & $\begin{array}{l}0.354 \\
(6.47)\end{array}$ & $\begin{array}{l}0.103 \\
(1.31)\end{array}$ & $\begin{array}{l}0.312 \\
(8.16)\end{array}$ & $\begin{array}{l}0.295 \\
(5.22)\end{array}$ & $\begin{array}{l}0.237 \\
(3.22)\end{array}$ & $\begin{array}{l}0.171 \\
(4.46)\end{array}$ \\
\hline Skill345 & $\begin{array}{l}-0.237 \\
(-2.96)\end{array}$ & $\begin{array}{l}-0.246 \\
(-3.04)\end{array}$ & $\begin{array}{l}-0.129 \\
(-1.48)\end{array}$ & $\begin{array}{l}-0.030 \\
(-0.19)\end{array}$ & & & $\begin{array}{l}0.030 \\
(0.26)\end{array}$ & $\begin{array}{l}0.078 \\
(1.11)\end{array}$ \\
\hline National mobility & $\begin{array}{l}0.182 \\
(1.97)\end{array}$ & $\begin{array}{l}-0.035 \\
(-0.44)\end{array}$ & $\begin{array}{l}0.121 \\
(1.27)\end{array}$ & $\begin{array}{l}0.205 \\
(2.18)\end{array}$ & $\begin{array}{l}-0.004 \\
(-0.06)\end{array}$ & $\begin{array}{l}0.162 \\
(2.14)\end{array}$ & $\begin{array}{l}0.012 \\
(0.10)\end{array}$ & $\begin{array}{l}0.025 \\
(0.39)\end{array}$ \\
\hline International mobility & $\begin{array}{l}-0.165 \\
(-1.34)\end{array}$ & $\begin{array}{l}0.005 \\
(0.06)\end{array}$ & $\begin{array}{l}-0.142 \\
(-1.54)\end{array}$ & $\begin{array}{l}0.030 \\
(0.29)\end{array}$ & $\begin{array}{l}-0.124 \\
(-1.03)\end{array}$ & $\begin{array}{l}0.083 \\
(0.91)\end{array}$ & $\begin{array}{l}-0.217 \\
(-1.39)\end{array}$ & $\begin{array}{l}-0.137 \\
(-1.81)\end{array}$ \\
\hline Never 1 & $\begin{array}{l}-0.187 \\
(-1.05)\end{array}$ & $\begin{array}{l}0.140 \\
(1.86)\end{array}$ & $\begin{array}{l}0.028 \\
(0.33)\end{array}$ & $\begin{array}{l}-0.091 \\
(-0.58)\end{array}$ & $\begin{array}{l}0.091 \\
(0.66)\end{array}$ & $\begin{array}{l}-0.153 \\
(-1.53)\end{array}$ & $\begin{array}{l}0.162 \\
(1.21)\end{array}$ & $\begin{array}{l}0.120 \\
(1.20)\end{array}$ \\
\hline Age & $\begin{array}{l}0.013 \\
(3.53)\end{array}$ & $\begin{array}{l}0.007 \\
(2.88)\end{array}$ & $\begin{array}{l}-0.005 \\
(-1.31)\end{array}$ & $\begin{array}{c}0.000 \\
(-0.13)\end{array}$ & $\begin{array}{l}-0.003 \\
(-1.46)\end{array}$ & $\begin{array}{l}-0.005 \\
(-2.58)\end{array}$ & $\begin{array}{l}0.014 \\
(2.70)\end{array}$ & $\begin{array}{l}0.004 \\
(2.03)\end{array}$ \\
\hline Woman & $\begin{array}{l}0.201 \\
(2.58)\end{array}$ & $\begin{array}{l}0.242 \\
(3.37)\end{array}$ & $\begin{array}{l}0.169 \\
(2.12)\end{array}$ & $\begin{array}{l}0.083 \\
(0.89)\end{array}$ & $\begin{array}{l}0.389 \\
(6.32)\end{array}$ & $\begin{array}{l}0.127 \\
(1.96)\end{array}$ & $\begin{array}{l}0.003 \\
(0.03)\end{array}$ & $\begin{array}{l}0.133 \\
(2.25)\end{array}$ \\
\hline Married & $\begin{array}{l}0.218 \\
(2.58)\end{array}$ & $\begin{array}{l}-0.177 \\
(-2.27)\end{array}$ & $\begin{array}{l}0.090 \\
(1.03)\end{array}$ & $\begin{array}{l}0.071 \\
(0.68)\end{array}$ & $\begin{array}{l}-0.070 \\
(-0.99)\end{array}$ & $\begin{array}{l}0.138 \\
(2.00)\end{array}$ & $\begin{array}{l}-0.179 \\
(-1.43)\end{array}$ & $\begin{array}{l}0.038 \\
(0.62)\end{array}$ \\
\hline Catholic & & $\begin{array}{l}-0.070 \\
(-0.69) \\
\end{array}$ & $\begin{array}{l}0.187 \\
(2.24) \\
\end{array}$ & $\begin{array}{l}-0.053 \\
(-0.45) \\
\end{array}$ & $\begin{array}{r}0.415 \\
(1.09) \\
\end{array}$ & $\begin{array}{r}0.433 \\
(3.72) \\
\end{array}$ & $\begin{array}{l}0.376 \\
(2.47) \\
\end{array}$ & $\begin{array}{r}0.087 \\
(1.44) \\
\end{array}$ \\
\hline$\overline{\text { Cut1 }}$ & 0.653 & 0.222 & -0.305 & -1.653 & 0.619 & -0.770 & 0.124 & 0.285 \\
\hline Cut2 & 1.486 & 1.285 & 0.767 & -0.121 & 1.127 & 0.375 & 0.786 & 1.050 \\
\hline Cut3 & 2.053 & 1.931 & 1.536 & 0.442 & 2.099 & 1.107 & 1.264 & 1.651 \\
\hline Cut4 & 2.774 & 3.001 & 2.591 & 1.968 & 2.718 & 2.543 & 1.834 & 2.455 \\
\hline Number of obs & 821 & 893 & 727 & 630 & 1228 & 1184 & 418 & 1346 \\
\hline LR chi2 & 127.990 & 159.410 & 81.440 & 14.850 & 166.810 & 107.660 & 47.200 & 204.910 \\
\hline Prob $>$ chi 2 & 0.000 & 0.000 & 0.000 & 0.138 & 0.000 & 0.000 & 0.000 & 0.000 \\
\hline Pseudo R2 & 0.052 & 0.060 & 0.038 & 0.010 & 0.044 & 0.036 & 0.041 & 0.049 \\
\hline Log likelihood & -1177.318 & -1252.144 & -1034.937 & -775.849 & -1817.111 & -1425.143 & -546.282 & -1970.547 \\
\hline
\end{tabular}

Source: see text. T-statistics are in parentheses. 
Table 7. Sensitivity analysis

Dependent variable is protect. Country dummies included (coefficients not reported)

\begin{tabular}{|c|c|c|c|c|c|c|c|c|}
\hline Equation & $(1)$ & $(2)$ & (3) & $(4)$ & $(5)$ & $(6)$ & $(7)$ & $(8)$ \\
\hline$\overline{\text { Sample }}$ & West only & East only & West only & East only & Men only & $\begin{array}{l}\text { Women } \\
\text { only }\end{array}$ & $\begin{array}{c}\text { Immobile } \\
\text { only }\end{array}$ & $\begin{array}{c}\text { Mobile } \\
\text { only }\end{array}$ \\
\hline \multirow{2}{*}{ Patriotism } & 0.1672 & 0.1809 & 0.1699 & 0.1670 & 0.1772 & 0.1793 & 0.1760 & 0.1710 \\
\hline & (13.08) & (10.18) & $(9.42)$ & (7.20) & (12.36) & $(12.26)$ & (11.45) & (12.42) \\
\hline \multirow[t]{2}{*}{ Chauvinism } & 0.3692 & 0.2766 & 0.3463 & 0.2938 & 0.3340 & 0.3250 & 0.3240 & 0.3350 \\
\hline & (30.64) & $(16.01)$ & (20.17) & $(12.85)$ & (24.37) & $(23.33)$ & $(22.61)$ & $(25.07)$ \\
\hline \multirow[t]{2}{*}{ Skill345 } & -0.1647 & 0.1037 & -0.6101 & 0.1192 & -0.0840 & 0.0517 & 0.0240 & -0.0640 \\
\hline & $(-1.01)$ & $(1.66)$ & $(-1.83)$ & $(1.24)$ & $(-1.41)$ & $(0.96)$ & $(0.44)$ & $(-1.08)$ \\
\hline \multirow[t]{2}{*}{ Skill345*GDPCAP } & -0.0027 & -0.0246 & 0.0205 & -0.0329 & -0.0110 & -0.0079 & -0.0128 & -0.0067 \\
\hline & $(-0.35)$ & $(-3.33)$ & $(1.24)$ & $(-2.53)$ & $(-3.26)$ & $(-2.55)$ & $(-3.74)$ & $(-2.08)$ \\
\hline \multirow[t]{2}{*}{ National mobility } & -0.0089 & -0.0080 & 0.0260 & -0.0071 & -0.0111 & -0.0003 & & \\
\hline & $(-0.46)$ & $(-0.29)$ & $(0.96)$ & $(-0.20)$ & $(-0.50)$ & $(-0.02)$ & & \\
\hline \multirow{2}{*}{$\begin{array}{l}\text { In ternationa } 1 \\
\text { mobility }\end{array}$} & -0.1150 & -0.1380 & -0.1380 & -0.1195 & -0.0936 & -0.1476 & -0.1510 & -0.1230 \\
\hline & $(-5.01)$ & $(-3.78)$ & $(-4.47)$ & $(-2.43)$ & $(-3.54)$ & $(-5.37)$ & $(-3.55)$ & $(-5.69)$ \\
\hline \multirow[t]{2}{*}{ Never lived abroad } & 0.1200 & 0.0861 & 0.1501 & 0.0574 & 0.1483 & 0.0646 & 0.1090 & 0.1010 \\
\hline & $(5.63)$ & $(2.19)$ & $(5.24)$ & $(1.12)$ & $(5.85)$ & $(2.38)$ & $(3.82)$ & (4.14) \\
\hline \multirow[t]{2}{*}{ Age } & 0.0003 & 0.0038 & 0.0015 & 0.0052 & 0.0027 & 0.0008 & 0.0010 & 0.0020 \\
\hline & $(0.50)$ & $(4.28)$ & (1.51) & $(3.85)$ & (3.80) & $(1.22)$ & $(2.06)$ & (2.32) \\
\hline \multirow[t]{2}{*}{ Woman } & 0.2810 & 0.1187 & 0.3143 & 0.1041 & & & 0.1970 & 0.2490 \\
\hline & (16.42) & $(4.70)$ & (12.74) & $(3.11)$ & & & $(9.61)$ & $(13.03)$ \\
\hline \multirow[t]{2}{*}{ Married } & 0.0282 & 0.0487 & -0.0242 & 0.0275 & 0.0125 & 0.0349 & 0.0610 & 0.0040 \\
\hline & $(.54)$ & $(1.82)$ & $(-0.91)$ & $(0.74)$ & $(0.54)$ & (1.74) & $(2.76)$ & $(0.20)$ \\
\hline \multirow[t]{2}{*}{ Catholic } & 0.0472 & 0.0887 & 0.0593 & 0.0217 & 0.0852 & 0.0478 & 0.0680 & 0.0610 \\
\hline & (1.84) & $(2.70)$ & (1.64) & $(0.48)$ & $(3.06)$ & $(1.68)$ & $(2.24)$ & $(2.33)$ \\
\hline \multirow[t]{2}{*}{ Rural } & & & 0.1528 & 0.1496 & & & & \\
\hline & & & $(5.02)$ & $(3.98)$ & & & & \\
\hline \multirow[t]{2}{*}{ Unemployed } & & & 0.1067 & 0.0189 & & & & \\
\hline & & & $(1.48)$ & $(0.19)$ & & & & \\
\hline \multirow[t]{2}{*}{ Public sector } & & & 0.0035 & 0.0773 & & & & \\
\hline & & & $(0.13)$ & $(1.71)$ & & & & \\
\hline \multirow[t]{2}{*}{ Self-employed } & & & -0.0432 & -0.1055 & & & & \\
\hline & & & $(-1.18)$ & $(-1.52)$ & & & & \\
\hline \multirow[t]{2}{*}{ Trade union } & & & 0.0069 & 0.0100 & & & & \\
\hline & & & $(1.40)$ & $(0.75)$ & & & & \\
\hline$\overline{\text { Cut1 }}$ & 0.0053 & 0.1404 & -0.4000 & -0.1878 & 0.0844 & -0.4003 & -0.0110 & -0.0910 \\
\hline Cut2 & 1.0338 & 0.9306 & 0.7877 & 0.6078 & 1.0380 & 0.5692 & 0.8790 & 0.9080 \\
\hline Cut3 & 1.8017 & 1.5632 & 1.5314 & 1.2312 & 1.6756 & 1.3776 & 1.6260 & 1.6040 \\
\hline Cut4 & 2.9218 & 2.3338 & 2.6924 & 2.0111 & 2.6575 & 2.4011 & 2.5560 & 2.6810 \\
\hline No.obs. & 15977 & 7671 & 7887 & 4492 & 11811 & 12467 & 11499 & 12779 \\
\hline LRchi2 & 4556.3 & 1381.3 & 2058.3 & 833.9 & 3134.7 & 2822.2 & 2658.9 & 3280.1 \\
\hline Prob $>$ chi 2 & 0.0000 & 0.0000 & 0.0000 & 0.0000 & 0.0000 & 0.0000 & 0.0000 & 0.0000 \\
\hline PseudoR2 & 0.0957 & 0.0610 & 0.0885 & 0.0632 & 0.0866 & 0.0782 & 0.0780 & 0.0850 \\
\hline Loglikelihood & -21523.6 & -10640.3 & -10595.9 & -6176.5 & -16522.4 & -16631.2 & -15622.3 & -17579.1 \\
\hline
\end{tabular}

Source: see text. T-statistics are in parentheses. 
Table 8. Sensitivity analysis: labour force participation

Dependent variable is protect. Country dummies included (coefficients not reported)

\begin{tabular}{lcccccc}
\hline & $(1)$ & $(2)$ & $(3)$ & $(4)$ & $(5)$ & $(6)$ \\
\hline In labour force? & In LF & In LF & In LF & Not in LF & Not in LF & Not in LF \\
\hline Sample & All & West only & East only & All & West only & East only \\
\hline Patriotism & 0.1756 & 0.1521 & 0.2029 & 0.1780 & 0.2019 & 0.1239 \\
& $(14.03)$ & $(9.43)$ & $(9.64)$ & $(9.97)$ & $(9.53)$ & $(3.68)$ \\
Chauvinism & 0.3290 & 0.3718 & 0.2776 & 0.3309 & 0.3605 & 0.2789 \\
& $(27.60)$ & $(24.69)$ & $(13.58)$ & $(19.31)$ & $(17.75)$ & $(8.57)$ \\
Skill345 & -0.0661 & -0.1692 & 0.0337 & 0.1704 & 0.1633 & 0.3667 \\
& $(-1.46)$ & $(-0.87)$ & $(0.50)$ & $(1.95)$ & $(0.50)$ & $(1.86)$ \\
Skill345*GDPCAP & -0.0076 & -0.0029 & -0.0193 & -0.0177 & -0.0167 & -0.0498 \\
& $(-2.90)$ & $(-0.31)$ & $(-2.48)$ & $(-3.61)$ & $(-1.07)$ & $(-1.99)$ \\
National mobility & 0.0019 & 0.0098 & -0.0283 & -0.0243 & -0.0467 & 0.0364 \\
& $(0.10)$ & $(0.40)$ & $(-0.87)$ & $(-0.89)$ & $(-1.49)$ & $(0.65)$ \\
International mobility & -0.1131 & -0.1321 & -0.0955 & -0.1330 & -0.0801 & -0.2897 \\
& $(-5.07)$ & $(-4.76)$ & $(-2.33)$ & $(-3.63)$ & $(-1.94)$ & $(-3.55)$ \\
Never lived abroad & 0.1318 & 0.1481 & 0.1278 & 0.0624 & 0.0758 & 0.0240 \\
& $(5.76)$ & $(5.56)$ & $(2.64)$ & $(1.98)$ & $(2.12)$ & $(0.35)$ \\
Age & 0.0019 & 0.0000 & 0.0062 & 0.0009 & 0.0001 & 0.0032 \\
& $(2.30)$ & $(0.03)$ & $(4.18)$ & $(1.20)$ & $(0.08)$ & $(2.19)$ \\
Woman & 0.2435 & 0.3059 & 0.1497 & 0.1745 & 0.2316 & 0.0587 \\
& $(13.91)$ & $(13.78)$ & $(4.91)$ & $(7.07)$ & $(7.89)$ & $(1.26)$ \\
Married & -0.0036 & -0.0023 & -0.0143 & 0.1043 & 0.0903 & 0.1340 \\
& $(-0.19)$ & $(-0.09)$ & $(-0.42)$ & $(4.26)$ & $(3.09)$ & $(2.89)$ \\
Catholic & 0.0658 & 0.0441 & 0.0928 & 0.0659 & 0.0605 & 0.0707 \\
& $(2.75)$ & $(1.42)$ & $(2.31)$ & $(1.84)$ & $(1.31)$ & $(1.22)$ \\
\hline Cut1 & 0.0064 & -0.2033 & 0.3189 & -0.1850 & 0.0707 & -0.2083 \\
Cut2 & 0.9726 & 0.8476 & 1.1260 & 0.7451 & 1.0620 & 0.5484 \\
Cut3 & 1.6449 & 1.5838 & 1.7013 & 1.5629 & 1.8914 & 1.3419 \\
Cut4 & 2.6474 & 2.6954 & 2.4932 & 2.5683 & 3.0286 & 2.0781 \\
No.obs. & 15680 & 9808 & 5242 & 8598 & 6169 & 2429 \\
LRchi2 & 3774.6 & 2719.3 & 965.1 & 2212.1 & 1749.5 & 386.0 \\
Prob>chi2 & 0.0000 & 0.0000 & 0.0000 & 0.0000 & 0.0000 & 0.0000 \\
PseudoR2 & 0.0795 & 0.0921 & 0.0611 & 0.0887 & 0.0977 & 0.0572 \\
Loglikelihood & -21841.7 & -13403.0 & -7412.3 & -11360.9 & -8083.3 & -3179.0 \\
\hline
\end{tabular}

Source: see text. T-statistics are in parentheses. 
Table 9. Different age specifications

Dependent variable is protect. Country dummies included (coefficients not reported)

\begin{tabular}{|c|c|c|c|c|c|c|}
\hline & (1) & (2) & (3) & (4) & (5) & $(6)$ \\
\hline Sample & All & West only & East only & All & West only & East only \\
\hline \multirow[t]{2}{*}{ Patriotism } & 0.1752 & 0.1672 & 0.1812 & 0.1753 & 0.1663 & 0.1811 \\
\hline & $(17.16)$ & (13.07) & (10.19) & $(17.16)$ & (12.99) & (10.18) \\
\hline \multirow[t]{2}{*}{ Chauvinism } & 0.3305 & 0.3692 & 0.2772 & 0.3305 & 0.3690 & 0.2767 \\
\hline & (33.88) & $(30.62)$ & (16.04) & $(33.88)$ & $(30.61)$ & (16.01) \\
\hline \multirow[t]{2}{*}{ Skill345 } & -0.0227 & -0.1647 & 0.0948 & -0.0335 & -0.0717 & -0.0697 \\
\hline & $(-0.57)$ & $(-1.01)$ & $(1.52)$ & $(-0.55)$ & $(-0.41)$ & $(-0.67)$ \\
\hline \multirow[t]{2}{*}{ Skill345*age } & & & & 0.0003 & -0.0020 & 0.0038 \\
\hline & & & & $(0.24)$ & $(-1.55)$ & (1.99) \\
\hline \multirow[t]{2}{*}{ Skill345*GDPCAP } & -0.0095 & -0.0027 & -0.0244 & -0.0095 & -0.0029 & -0.0246 \\
\hline & $(-4.18)$ & $(-0.35)$ & $(-3.31)$ & $(-4.19)$ & $(-0.38)$ & $(-3.33)$ \\
\hline \multirow[t]{2}{*}{ National mobility } & -0.0058 & -0.0089 & -0.0105 & -0.0059 & -0.0085 & -0.0117 \\
\hline & $(-0.37)$ & $(-0.46)$ & $(-0.38)$ & $(-0.38)$ & $(-0.44)$ & $(-0.42)$ \\
\hline \multirow[t]{2}{*}{ International mobility } & -0.1170 & -0.1150 & -0.1345 & -0.1170 & -0.1160 & -0.1351 \\
\hline & $(-6.16)$ & $(-5.01)$ & $(-3.68)$ & $(-6.15)$ & $(-5.05)$ & $(-3.70)$ \\
\hline \multirow[t]{2}{*}{ Never lived abroad } & 0.1049 & 0.1199 & 0.0856 & 0.1050 & 0.1191 & 0.0892 \\
\hline & $(5.67)$ & $(5.63)$ & (2.18) & $(5.68)$ & $(5.59)$ & $(2.26)$ \\
\hline \multirow[t]{2}{*}{ Age } & 0.0054 & 0.0001 & 0.0148 & 0.0054 & 0.0003 & 0.0136 \\
\hline & (2.09) & $(0.05)$ & $(3.13)$ & $(2.07)$ & $(0.09)$ & $(2.86)$ \\
\hline \multirow[t]{2}{*}{ Age-squared } & 0.000000 & 0.000000 & -0.000100 & 0.000000 & 0.000000 & -0.000100 \\
\hline & $(-1.57)$ & $(0.05)$ & $(-2.37)$ & $(-1.58)$ & $(0.14)$ & $(-2.30)$ \\
\hline \multirow[t]{2}{*}{ Woman } & 0.2217 & 0.2810 & 0.1173 & 0.2220 & 0.2793 & 0.1213 \\
\hline & (15.93) & (16.42) & (4.64) & (15.90) & (16.29) & (4.79) \\
\hline \multirow[t]{2}{*}{ Married } & 0.0239 & 0.0286 & 0.0243 & 0.0240 & 0.0287 & 0.0264 \\
\hline & $(1.50)$ & $(1.44)$ & $(0.85)$ & $(1.50)$ & $(1.45)$ & $(0.92)$ \\
\hline \multirow[t]{2}{*}{ Catholic } & 0.0664 & 0.0472 & 0.0882 & 0.0665 & 0.0465 & 0.0888 \\
\hline & $(3.34)$ & $(1.84)$ & $(2.68)$ & $(3.35)$ & $(1.81)$ & $(2.70)$ \\
\hline$\overline{\text { Cut1 }}$ & 0.0274 & 0.2035 & 0.3440 & 0.0259 & 0.0135 & 0.3059 \\
\hline Cut2 & 0.9790 & 1.2319 & 1.1342 & 0.9776 & 1.0419 & 1.0961 \\
\hline Cut3 & 1.6965 & 1.9999 & 1.7670 & 1.6951 & 1.8099 & 1.7290 \\
\hline Cut4 & 2.6983 & 3.1200 & 2.5382 & 2.6969 & 2.9302 & 2.5006 \\
\hline No.obs. & 24278 & 15977 & 7671 & 24278 & 15977 & 7671 \\
\hline LRchi2 & 6068.4 & 4556.3 & 1386.9 & 6068.4 & 4558.7 & 1390.9 \\
\hline Prob $>$ chi 2 & 0.0000 & 0.0000 & 0.0000 & 0.0000 & 0.0000 & 0.0000 \\
\hline PseudoR2 & 0.0836 & 0.0957 & 0.0612 & 0.0836 & 0.0958 & 0.0614 \\
\hline Loglikelihood & -33280 & -21524 & -10637 & -33280 & -21522 & -10635 \\
\hline
\end{tabular}

Source: see text. T-statistics in parameters. 
Table 10. Simulating the impact on preferences of changing RHS variables

A. Equation (4), Table 4

Simulated Probability Mean Std. Dev. [95\% Conf. Interval]

\begin{tabular}{l|cccc}
$\operatorname{Pr}($ protect $==1)$ & .014755 & .0014167 & .0121608 & .0177452 \\
$\operatorname{Pr}($ protect $==2) \mid$ & .0954396 & .0055841 & .0846833 & .1061769 \\
$\operatorname{Pr}($ protect $==3) \mid$ & .195409 & .0062344 & .1829937 & .2076478 \\
$\operatorname{Pr}($ protect $==4) \mid$ & .3832816 & .0036822 & .376044 & .390276 \\
$\operatorname{Pr}($ protect $==5) \mid$ & .3111148 & .0128818 & .286102 & .3362912
\end{tabular}

First Difference: Change Patriotism from 40th to 60th percentile

Change in Probability Mean Std. Dev. [95\% Conf. Interval]

$\begin{array}{lllll}\mathrm{dPr}(\text { protect }==1) \mid & -.0023152 & .0002286 & -.0027948 & -.001922 \\ \mathrm{dPr}(\text { protect }==2) \mid & -.0090372 & .0006171 & -.0102836 & -.0079466 \\ \mathrm{~d} \operatorname{Pr}(\text { protect }==3) \mid & -.0093477 & .0005717 & -.0105066 & -.0082473 \\ \mathrm{dPr}(\text { protect }==4) \mid & .0004353 & .0007389 & -.0010632 & .001884 \\ \mathrm{dPr}(\text { protect }==5) \mid & .0202647 & .0012482 & .0178992 & .0227651\end{array}$

First Difference: Change Patriotism from 20th to 80th percentile

Change in Probability Mean Std. Dev. [95\% Conf. Interval]

\begin{tabular}{|c|c|c|c|c|}
\hline & 011789 & . 0011616 & -.0141546 & -.0097234 \\
\hline & 14. & .0030677 & -.051317 & -.0397028 \\
\hline ग) & -.046 & .0028001 & -.0520588 & -.0409887 \\
\hline$==4)$ & .0021564 & .0036593 & -.0052714 & .0093273 \\
\hline$=5$ & .1010716 & .0061935 & .0893281 & 1134693 \\
\hline
\end{tabular}

First Difference: Change Chauvinism from 40th to 60th percentile

Change in Probability Mean Std. Dev. [95\% Conf. Interval]

\begin{tabular}{|c|c|c|c|c|}
\hline & & .0005189 & 785 & 2 \\
\hline & -.0248 & .001137 & -.0270738 & -.022658 \\
\hline$==3$ & -.0266989 & .0009393 & -.0285721 & -.0249653 \\
\hline$==4)$ & -.0004574 & .0020837 & -.0047143 & .003624 \\
\hline$=5$ & .0582136 & .0020582 & .0541598 & . 06228 \\
\hline
\end{tabular}

First Difference: Change Chauvinism from 20th to 80th percentile

\begin{tabular}{lcccc} 
Change in Probability & Mean & Std. Dev. & {$[95 \%$ Conf. Interval] } \\
\hline $\mathrm{dPr}($ protect==1) $=-.0247046$ & .0020259 & -.0289362 & -.0207627 \\
$\mathrm{dPr}($ protect $==2) \mid$ & -.0900888 & .0039576 & -.097731 & -.0822445 \\
$\mathrm{dPr}($ protect $==3) \mid$ & -.0894131 & .0031579 & -.0956985 & -.083667 \\
$\operatorname{dPr}($ protect $==4) \mid$ & .0065264 & .0070095 & -.0078236 & .0199749 \\
$\operatorname{dPr}($ protect $==5) \mid$ & .1976801 & .0069093 & .1840308 & .2115107
\end{tabular}


A. Equation (4), Table 4 (continued)

First Difference: Impact of high-skill when GDP per capita $=\$ 5000$

\begin{tabular}{|c|c|c|c|}
\hline Change in Probability & Mean & Std. Dev. & [95\% Conf. Interval] \\
\hline $\mathrm{d} \operatorname{Pr}($ protect $==1)$ & .0026699 & .0012682 & $.0001494 \quad .0052034$ \\
\hline $\mathrm{dPr}($ protect $=2)$ & .0103182 & .004741 & $\begin{array}{ll}.0006345 & .0194862\end{array}$ \\
\hline $\mathrm{dPr}($ protect $==3)$ & .0105686 & .0047525 & $\begin{array}{ll}.0006773 & .0195221\end{array}$ \\
\hline $\mathrm{dPr}($ protect $==4)$ & -.0006657 & .0010204 & $\begin{array}{ll}-.0030787 & .0010019\end{array}$ \\
\hline $\mathrm{dPr}($ protect $==5)$ & -.0228909 & .0102694 & $-.0420419 \quad-.0014672$ \\
\hline
\end{tabular}

First Difference: Impact of high-skill when GDP per capita $=\$ 15000$

\begin{tabular}{|c|c|c|c|c|}
\hline Change in Probability & Mean & Std. Dev. & {$[95 \%$ Conf } & f. Interval] \\
\hline 1) & .0072067 & .0009877 & .0053957 & .0093273 \\
\hline $\mathrm{dPr}($ protect $==2)$ & .0263177 & .002958 & .0206797 & .0324438 \\
\hline $\mathrm{d} \operatorname{Pr}($ protect $==3)$ & .025299 & .0026539 & .0202207 & .0305039 \\
\hline $\mathrm{dPr}($ protect $==4)$ & -.0041574 & .0021097 & -.0083383 & -.0003163 \\
\hline $\mathrm{dPr}($ protect $=5)$ & -.0546661 & .0057117 & -.0655149 & -.0436477 \\
\hline
\end{tabular}

First Difference: Impact of high-skill when GDP per capita $=\$ 25000$

\begin{tabular}{|c|c|c|c|}
\hline Change in Probability | & Mean & Std. Dev. & [95\% Conf. Interval] \\
\hline $\operatorname{Pr}($ protect & .0127708 & .0020405 & $\begin{array}{ll}.0090668 & .0170057\end{array}$ \\
\hline $\mathrm{dPr}($ protect $==2)$ & .0436224 & .0054026 & $\begin{array}{ll}.0330583 & .0541702\end{array}$ \\
\hline $\mathrm{dPr}($ protect $==3)$ & .0389498 & .003894 & $\begin{array}{ll}.0312127 & .0462664\end{array}$ \\
\hline $\mathrm{dPr}($ protect $=4) \mid-$ & -.0109429 & .004037 & $\begin{array}{ll}-.019564 & -.0036387\end{array}$ \\
\hline $\mathrm{dPr}($ protect $=5) \mid-$ & -.0844001 & .008483 & $\begin{array}{ll}-.1006383 & -.0677581\end{array}$ \\
\hline
\end{tabular}

First Difference: Impact of national mobility

Change in Probability $\mid$ Mean Std. Dev. [95\% Conf. Interval]

$\begin{array}{lllll}\mathrm{dPr}(\text { protect= }=1) \mid & .0001647 & .000602 & -.0009862 & .0013277 \\ \mathrm{dPr}(\text { protect }=2) & .0006607 & .0024323 & -.0039293 & .0052194 \\ \mathrm{dPr}(\text { protect==3) } & .0007024 & .002618 & -.004298 & .0055967 \\ \mathrm{dPr}(\text { protect }==4) \mid & -3.03 \mathrm{e}-06 & .0002122 & -.0004342 & .0004178 \\ \mathrm{dPr}(\text { protect }=5) & -.0015247 & .0056915 & -.0121468 & .0094165\end{array}$

First Difference: Impact of international mobility

\begin{tabular}{|c|c|c|c|c|}
\hline Change in Probability & Mean & Std. Dev. & {$[95 \%$ Conf } & f. Interval] \\
\hline $\operatorname{Pr}($ protect $==1)$ & .0049903 & .0009142 & .0032012 & .0068706 \\
\hline $\mathrm{dPr}($ protect $==2)$ & .0187507 & .0030806 & .0125397 & .0248353 \\
\hline $\mathrm{dPr}($ protect $=3)$ & .0185949 & .0029016 & .0125033 & .024531 \\
\hline $\mathrm{dPr}($ protect $=4)$ & -.0021242 & .0015527 & -.0053734 & 0007657 \\
\hline $\mathrm{dPr}($ protect $=5)$ & -.0402116 & .0062809 & -.0528894 & -.0271189 \\
\hline
\end{tabular}


A. Equation (4), Table 4 (continued)

First Difference: Impact of never having lived abroad

\begin{tabular}{lllll} 
Change in Probability $\mid$ & Mean & Std. Dev. & {$[95 \%$ Conf. Interval $]$} \\
\hline $\mathrm{dPr}($ protect=-=1) $\mid$ & -.0043958 & .0009459 & -.0064719 & -.0026324 \\
$\mathrm{dPr}($ protect $==2) \mid$ & -.0166275 & .0031617 & -.0230548 & -.0104391 \\
$\mathrm{dPr}($ protect $==3) \mid$ & -.016615 & .0029039 & -.0221301 & -.010629 \\
$\mathrm{dPr}($ protect $==4) \mid$ & .0017006 & .0015057 & -.0010203 & .0051738 \\
$\mathrm{dPr}($ protect $==5) \mid$ & .0359378 & .006238 & .0227924 & .0476815
\end{tabular}

First Difference: Impact of changing age from 30 to 60

\begin{tabular}{ccccc} 
Change in Probability $\mid$ & Mean & Std. Dev. & {$[95 \%$ Conf. Interval $]$} \\
\hline $\mathrm{dPr}($ protect $==1) \mid$ & -.0015981 & .0005331 & -.0026549 & -.0005986 \\
$\mathrm{dPr}($ protect $==2) \mid$ & -.0064954 & .002123 & -.010649 & -.0024426 \\
$\mathrm{dPr}($ protect $==3) \mid$ & -.007031 & .0023066 & -.0115803 & -.0026377 \\
$\mathrm{dPr}($ protect $==4) \mid$ & -.0001971 & .0005872 & -.0014513 & .0008854 \\
$\mathrm{dPr}($ protect $==5) \mid$ & .0153217 & .0050335 & .0057954 & .025114
\end{tabular}

First Difference: Impact of being female

\begin{tabular}{ccccc} 
Change in Probability $\mid$ & Mean & Std. Dev. & {$[95 \%$ Conf. Interval] } \\
\hline $\mathrm{dPr}($ protect==1) $=-.0105906$ & .0009866 & -.0127733 & -.0087948 \\
$\mathrm{dPr}($ protect==2) & -.0371693 & .0025282 & -.0422877 & -.0322484 \\
$\operatorname{dPr}($ protect $==3) \mid$ & -.0341823 & .0023486 & -.0386092 & -.0295846 \\
$\operatorname{dPr}($ protect $==4) \mid$ & .0080248 & .0027035 & .0025342 & .0136012 \\
$\operatorname{dPr}($ protect $==5) \mid$ & .0739175 & .0049386 & .0640913 & .0829416
\end{tabular}

First Difference: Impact of being married or living as married

\begin{tabular}{ccccc} 
Change in Probability $\mid$ & Mean & Std. Dev. & [95\% Conf. Interval] \\
\hline $\mathrm{dPr}($ protect=-=1) & -.0013144 & .0005919 & -.002546 & -.0002151 \\
$\mathrm{dPr}($ protect $==2) \mid$ & -.0051992 & .0022952 & -.009917 & -.0009015 \\
$\mathrm{dPr}($ protect $==3) \mid$ & -.0054664 & .0023992 & -.01021 & -.0009952 \\
$\mathrm{dPr}($ protect $==4) \mid$ & .0001146 & .0004661 & -.0008027 & .0011273 \\
$\mathrm{dPr}($ protect $==5) \mid$ & .0118654 & .0052007 & .0021536 & .0223169
\end{tabular}

First Difference: Impact of being a Roman Catholic

\begin{tabular}{|c|c|c|c|}
\hline Change in Probability & Mean & Std. Dev. & [95\% Conf. Interval] \\
\hline $\mathrm{dPr}($ protect $==1) \mid$ & -.0023132 & .0007333 & $\begin{array}{ll}-.0038933 & -.0009683\end{array}$ \\
\hline $\mathrm{dPr}($ protect $==2)$ & -.0097175 & .0029776 & $\begin{array}{ll}-.0159036 & -.0042047\end{array}$ \\
\hline $\mathrm{dPr}($ protect $==3)$ & -.0109054 & .0033224 & $\begin{array}{ll}-.0176632 & -.0046724\end{array}$ \\
\hline $\mathrm{dPr}($ protect $=4)$ & -.0009572 & .0008932 & $\begin{array}{ll}-.0029647 & .0005849\end{array}$ \\
\hline $\mathrm{dPr}($ protect $=5)$ & .0238934 & .0072726 & $\begin{array}{ll}.0102972 & .0384006\end{array}$ \\
\hline
\end{tabular}


B. Equation (5), Table 4

Simulated Probability $\mid \quad$ Mean Std. Dev. [95\% Conf. Interval]

$\begin{array}{lllll}\operatorname{Pr}(\text { protect==1) } & .0174649 & .002789 & .0127167 & .0233261 \\ \operatorname{Pr}(\text { protect==2) } & .1264871 & .0114484 & .1065978 & .1500246 \\ \operatorname{Pr}(\text { protect==3) } & .2110957 & .009337 & .1925624 & .2294772 \\ \operatorname{Pr}(\text { protect==4) } & .3859744 & .0055172 & .3751257 & .3963836 \\ \operatorname{Pr}(\text { protect==5) } & .2589779 & .0198112 & .2198795 & .2959962\end{array}$

First Difference: Impact of being rural

\begin{tabular}{|c|c|c|c|}
\hline Change in Probability & Mean & Std. Dev. & [95\% Conf. Interval] \\
\hline $\mathrm{dPr}($ protect $==1)$ & -.0049403 & .0010727 & $\begin{array}{ll}-.0071378 & -.0030334\end{array}$ \\
\hline $\mathrm{dPr}($ protect $==2)$ & -.0228495 & .0041677 & $\begin{array}{ll}-.0308445 & -.0147179\end{array}$ \\
\hline $\mathrm{dPr}($ protect $==3)$ & -.0199502 & .0036924 & $\begin{array}{ll}-.0268114 & -.0128275\end{array}$ \\
\hline $\mathrm{dPr}($ protect $=4)$ & .0033016 & .0028547 & -.0020696 \\
\hline $\mathrm{dPr}($ protect $==5)$ & .0444383 & .0082096 & $\begin{array}{ll}.0288076 & .0594362\end{array}$ \\
\hline
\end{tabular}

First Difference: Impact of being unemployed

\begin{tabular}{|c|c|c|c|c|}
\hline Change in Probability & Mean & Std. Dev. & {$[95 \% \mathrm{Co}$} & val] \\
\hline rotect & -.0023965 & .0022055 & -.0065941 & .0020396 \\
\hline $\mathrm{dPr}($ protect $=2)$ & -.0109467 & .0099035 & -.0300374 & .008259 \\
\hline $\mathrm{dPr}($ protect $==3)$ & -.0094249 & .0085891 & -.0270617 & .006401 \\
\hline $\mathrm{dPr}($ protect $==4)$ & .0017947 & .0024421 & -.00296 & .0070637 \\
\hline $\mathrm{dPr}($ protect $==5)$ & .0209735 & .0191444 & -.0142154 & - 060015 \\
\hline
\end{tabular}

First Difference: Impact of working in public sector

Change in Probability $\mid$ Mean Std. Dev. [95\% Conf. Interval]

$\begin{array}{lllll}\mathrm{dPr}(\text { protect==1) } & -.0015352 & .0009784 & -.0034262 & .0003988 \\ \mathrm{dPr}(\text { protect==2) } & -.0067115 & .0042186 & -.0146584 & .0016643 \\ \mathrm{dPr}(\text { protect }==3) \mid & -.0054888 & .0034838 & -.0121543 & .0013485 \\ \mathrm{dPr}(\text { protect }==4) \mid & .0015316 & .0012789 & -.0004131 & .0044134 \\ \mathrm{~d} \operatorname{Pr}(\text { protect }==5) \mid & .0122039 & .0077459 & -.0029597 & .0272057\end{array}$

First Difference: Impact of being self-employed

\begin{tabular}{ccccc} 
Change in Probability & Mean & Std. Dev. & [95\% Conf. Interval] \\
\hline $\mathrm{dPr}($ protect $==1)$ & .003982 & .0015977 & .0011853 & .0072821 \\
$\mathrm{dPr}($ protect $==2) \mid$ & .0159954 & .0059724 & .0050317 & .0280853 \\
$\mathrm{dPr}($ protect $==3) \mid$ & .0118232 & .0043245 & .0040024 & .0206445 \\
$\mathrm{dPr}($ protect $==4)$ & -.0053709 & .0028221 & -.0116064 & -.0010744 \\
$\mathrm{dPr}($ protect $==5)$ & -.0264298 & .0096174 & -.0462615 & -.0088937
\end{tabular}

First Difference: Impact of belonging to a trade union

\begin{tabular}{ccccc} 
Change in Probability $\mid$ & Mean & Std. Dev. & {$[95 \%$ Conf. Interval $]$} \\
\hline $\mathrm{dPr}($ protect==1) & -.0003211 & .0002013 & -.0007417 & .0000625 \\
$\mathrm{dPr}($ protect==2) & -.0013806 & .00085 & -.003074 & .0002784 \\
$\mathrm{dPr}(\operatorname{protect}==3) \mid$ & -.0011037 & .0006855 & -.0024854 & .000232 \\
$\mathrm{dPr}($ protect $==4) \mid$ & .0003517 & .0002788 & -.0000952 & .0010108 \\
$\mathrm{dPr}($ protect $==5) \mid$ & .0024536 & .0015179 & -.0005132 & .0055294
\end{tabular}

Source: see text. 


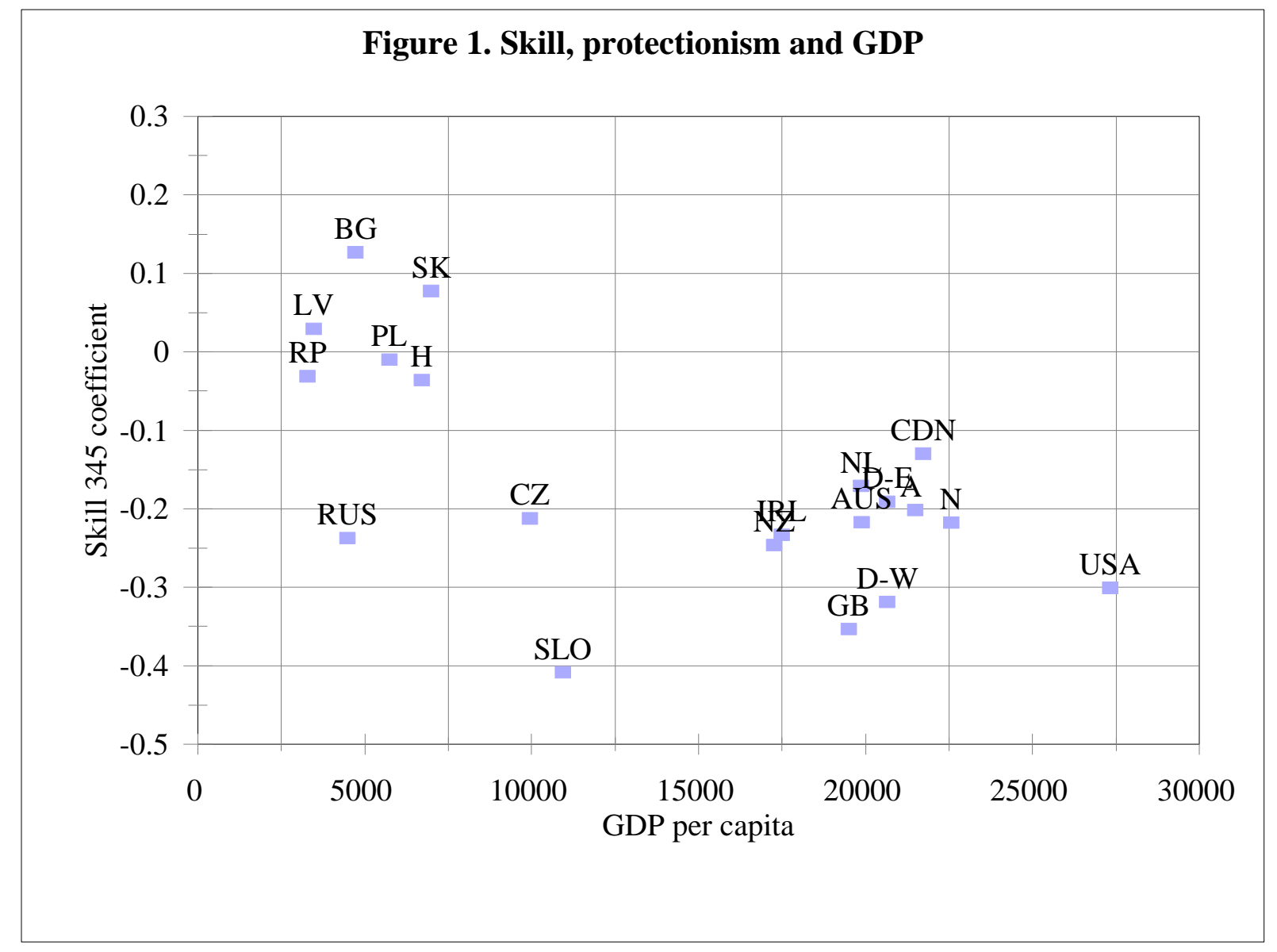


Figure 2. Skill, protectionism \& H/L

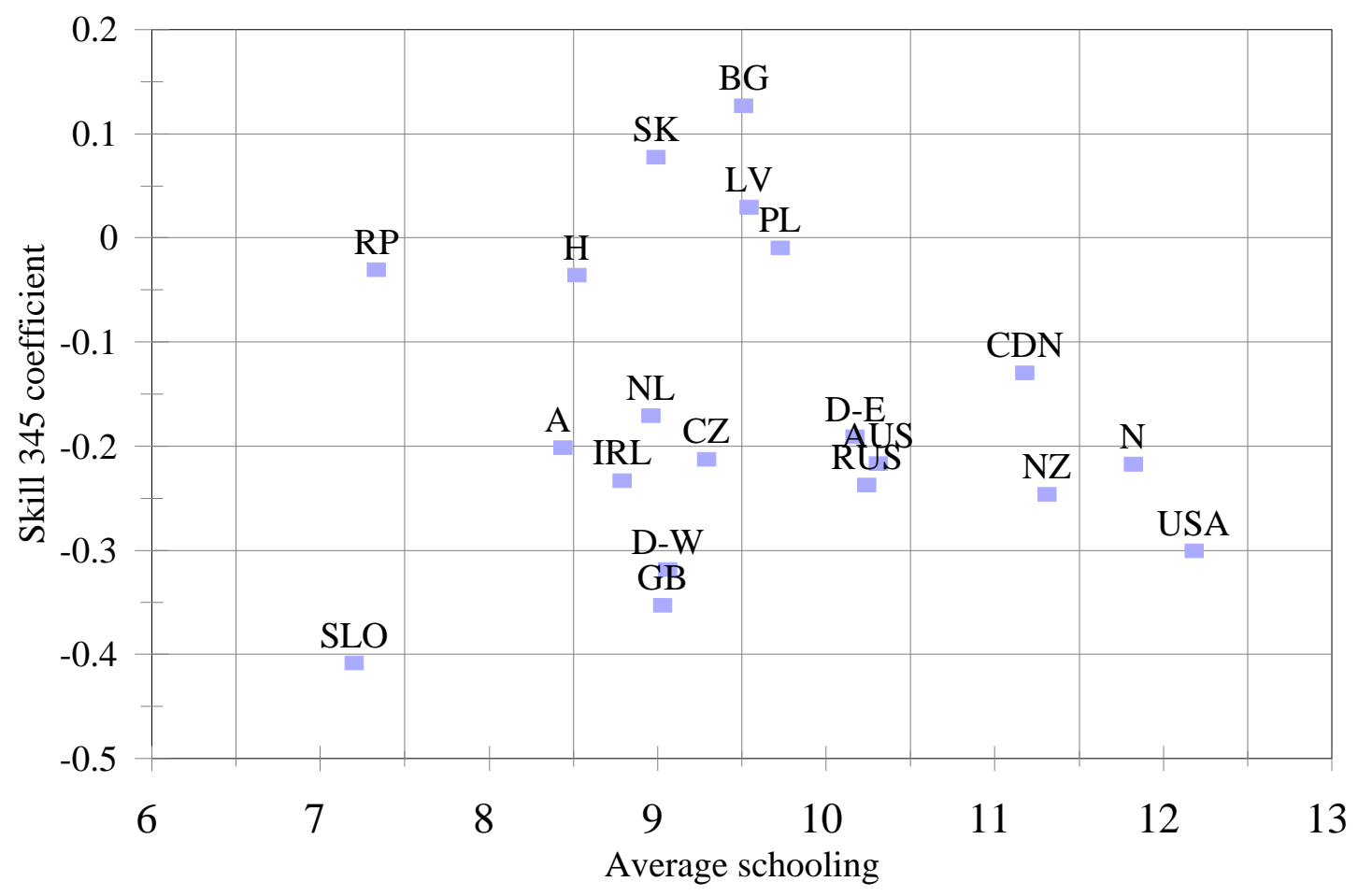

